Article

\title{
Exploring Themes of Sustainable Practices in Manufacturing Industry: Using Thematic Networks Approach
}

\author{
Noor Ullah Khan ${ }^{1,2} \oplus$, Haoqiang Wei ${ }^{3, *}$, Guiling Yue ${ }^{4}$, Nabila Nazir ${ }^{5}$ and Noor Raihani Zainol ${ }^{1} \mathbb{C}$ \\ 1 Faculty of Entrepreneurship and Business, Universiti Malaysia Kelantan (UMK), Kota Bharu 16100, Malaysia; \\ noorullah@umk.edu.my (N.U.K.); raihani@umk.edu.my (N.R.Z.) \\ 2 Department of HRM, NUST Business School, National University of Sciences and Technology, \\ Islamabad 44000, Pakistan \\ 3 Department of Audit, Shanghai National Accounting Institute, Shanghai 201702, China \\ 4 School of Human Resource Development \& Psychology, Universiti Teknologi Malaysia, \\ Johor Bahru 81310, Malaysia; guiling-1994@graduate.utm.my \\ 5 Department of Management Sciences, Comsats University, Islamabad 44000, Pakistan; nabila@comsats.edu.pk \\ * Correspondence: weihaoqiang@snai.edu
}

Citation: Khan, N.U.; Wei, H.; Yue, G.; Nazir, N.; Zainol, N.R. Exploring Themes of Sustainable Practices in Manufacturing Industry: Using Thematic Networks Approach. Sustainability 2021, 13, 10288. https:// doi.org/10.3390/su131810288

Academic Editors: Maria Rosa Trovato and Dalia Štreimikienè

Received: 31 July 2021

Accepted: 10 September 2021

Published: 15 September 2021

Publisher's Note: MDPI stays neutra with regard to jurisdictional claims in published maps and institutional affiliations.

Copyright: (c) 2021 by the authors. Licensee MDPI, Basel, Switzerland This article is an open access article distributed under the terms and conditions of the Creative Commons Attribution (CC BY) license (https:// creativecommons.org/licenses/by/ $4.0 /)$

\begin{abstract}
Sustainability is a vital strategy for manufacturing industries to address major environmental issues. Stakeholders' growing ecological awareness is forcing manufacturers to adopt green human resource management practices (green HRM practices) and environmental management systems (EMS) to improve sustainable performance (SP). This research explores the key themes of green HRM practices, EMS, and OCBE, and how these themes affect the environment and explain SP among ISO14001-certified manufacturing firms. This research used a qualitative methodology following an interpretivist approach. It employed the thematic networks technique, using qualitative data to achieve the objectives. The qualitative data were collected using semi-structured interviews conducted with HR managers and then analyzed using NVivo 12. Thematic network analysis explores basic and organizing themes within qualitative data. Four central (parent) themes, i.e., green HRM practices, OCBE, EMS, and SP, emerged. First, green HRM was sub-divided into three sub-themes: (i) green recruitment and selection, (ii) green training and development, and (iii) green assessment and rewards. Consequently, OCBE was then sub-divided into three themes: (i) eco-helping behavior, (ii) eco-initiatives behavior, and (iii) eco-civic engagement behavior emerged. Likewise, EMS was sub-divided into three themes: (i) ISO14001, (ii) EMS key benefits, and (iii) EMS key motives. Lastly, SP was further divided into three sub-themes: (i) economic, (ii) social, and (iii) environmental. This research also discusses important implications for managers and organizations.
\end{abstract}

Keywords: green HRM practices; organizational citizenship behavior for the environment; environmental management system; sustainable performance; thematic networks approach

\section{Introduction}

There is now an urgency for businesses to employ sustainable practices in their operations. Managing the environment effectively is possible when the framework of economic prosperity, ecological wealth, and human well-being functions well [1,2]. For many decades most business organizations focused only on growth and making profits. This preoccupation neglected sustainable performance (SP), and so the key components of social and environmental security that are vital for human well-being were ignored. Today, the world is subjected to the dangers of global warming, rising carbon emissions, and pollution, causing environmental degradation [3,4]. This calls for serious action on the part of manufacturers to address these challenges by integrating sustainable practices into their everyday practices, be it human resource processes or production. Moreover, the ever-burgeoning environmental awareness among many stakeholder groups has compelled manufacturers and other producers to implement green human resource management 
(HRM) practices [5]. They can do this by further embracing the environmental management systems (EMS) and pro-environmental behaviors (PEB) to enhance SP [6-9].

The manufacturing sector plays a significant role in the Malaysian economy. An estimated $23.80 \%$ of its gross domestic product (GDP) derives from manufacturing companies, according to Ministry of International Trade and Industry (MITI) statistics. Producing goods and services has a dominant position in the country's economy, as well as internationally $[10,11]$. However, this burgeoning contribution comes at a high cost, in that the country is bearing the brunt of the damage to the environment, leading to a plethora of sustainability issues. Consequently, Malaysian companies must adopt a proactive approach to sustainable performance and integrate environmental management systems (EMS). This means implementing widely accepted environmental standards to meaningfully improve how society operates [12]. EMS provides useful guidelines to the manufacturing sector for managing environmental issues [10], and it is a voluntary-based system for organizations to adhere to. It contains a set of practices and processes by which organizations can compete better and curtail the environmental impacts of their operations [13]. Various aspects of PEB have remained understudied. Organizational citizenship behavior for the environment (OCBE) is a relatively new, but key, feature of PEB. It is informal and voluntary. 'Corporate greening' considers OCBE essential, and it should be practiced by all staff in an organization [14-16].

Recent research investigated key antecedents of OCBE. Researchers in this field have discovered a range of factors governing and supporting OCBE-related strategies. For instance, Terrier et al. [17] focus our attention on the importance of personality traits; for instance, psychological empowerment is emphasized by Lamm et al. [18]. For Paillé et al. [19], the intention to support other personnel is pivotal. Liu et al. [20] note the importance of perceived control of behavior and values related to the environment. Paillé, Mejía-Morelos, Marché-Paillé, Chen, and Chen [19] explain the critical role of managerial support and commitment to environmental issues. Last but not least, Gurmani, Khan, Khalique, Yasir, Obaid, and Sabri [15] place their emphasis on environmental transformational leadership and perceived meaningful work in predicting OCBE; while a number of scholars have also highlighted different types of OCBE. The two fundamental types, of utmost importance to date, include, first, the behavior that is most direct in achieving the results, such as conservation of energy, engagement in recyclable initiatives, etc.; and second, the behaviors that are more indirect [5]. Included here are involvement in environmental initiatives by civic groups and related clean-up activities [19]. The five taxonomies of green behavior are deemed to be key features of OCBE [21,22]. Furthermore, the factors relevant to OCBE that operate at the management, unit, and employee levels have been explored $[9,23,24]$. The existing scholarship encourages attention be paid to the determinants of OCBE, to improve sustainable performance and employ an environmental management system [25,26]. More recently, antecedents for sustainable performance have been explored, especially the significance of environmentally friendly behaviors that should be conducted by the corporate sector $[27,28]$. However, scant research has been published on the critical themes of green HRM practices, OCBE, EMS, and SP.

The present study addresses this gap by exploring three key themes that explain SP among ISO14001-certified Malaysian manufacturing firms: green HRM practices, environmental management systems (EMS), and organizational citizenship behavior for the environment (OCBE). This paper briefly introduces sustainability and addresses the challenges of manufacturing firms. The key constructs of green HRM practices, EMS, OCBE, and SP are discussed. This is followed by explaining the qualitative methodology. The subsequent sections discuss in detail the data analysis results and interpretation. Finally, the last section presents a comprehensive discussion of the key findings, major limitations, and conclusions. 


\section{Literature Review}

In this section, the scholarship on green HRM practices, EMS ISO14001, OCBE, and $\mathrm{SP}$ is reviewed. Two main streams of OCBE include voluntary and prescribed tasks. Furthermore, sustainable performance as an integrative concept is examined in the context of economic, social, and environmental dimensions.

\subsection{Green HRM Practices under the Sustainable HRM Umbrella}

Sustainable HRM is still an emerging concept [29], and most of the work on it has been primarily exploratory in nature. Earlier research concentrated on environmental management (EM) and corporate sustainability (CS), based on the human relations tradition and the Harvard Approach. The literature on sustainable HRM has highlighted four main perspectives linking HRM and sustainability [30,31]. In discussing sustainability in HRM, four main approaches were discussed, i.e., psychological, sociological, strategic, and green (see Mazur [30]). Sustainable human resource management (HRM) is a relatively new research topic; whereas, in the past, a lack of research on systematic links between sustainability and HRM was evident. The above-mentioned four approaches are vital for explaining how sustainability emerged and became refined in HRM practices (see Figure 1). The psychological perspective focuses on the drivers that characterize employees' workplace priorities and responsibilities, e.g., work-life balance. The sociological perspective explains the relationships and mechanisms between employer, employees, and the wider society. The strategic perspective builds upon the resource-based view (RBV). It explains the long-term focus of organizations on how human resources help achieve a sustainable competitive advantage [30]. It also recognizes the importance of viewing 'corporate greening' from an array of perspectives. These include, but are not limited to, sociological, psychological, and strategic outlooks.

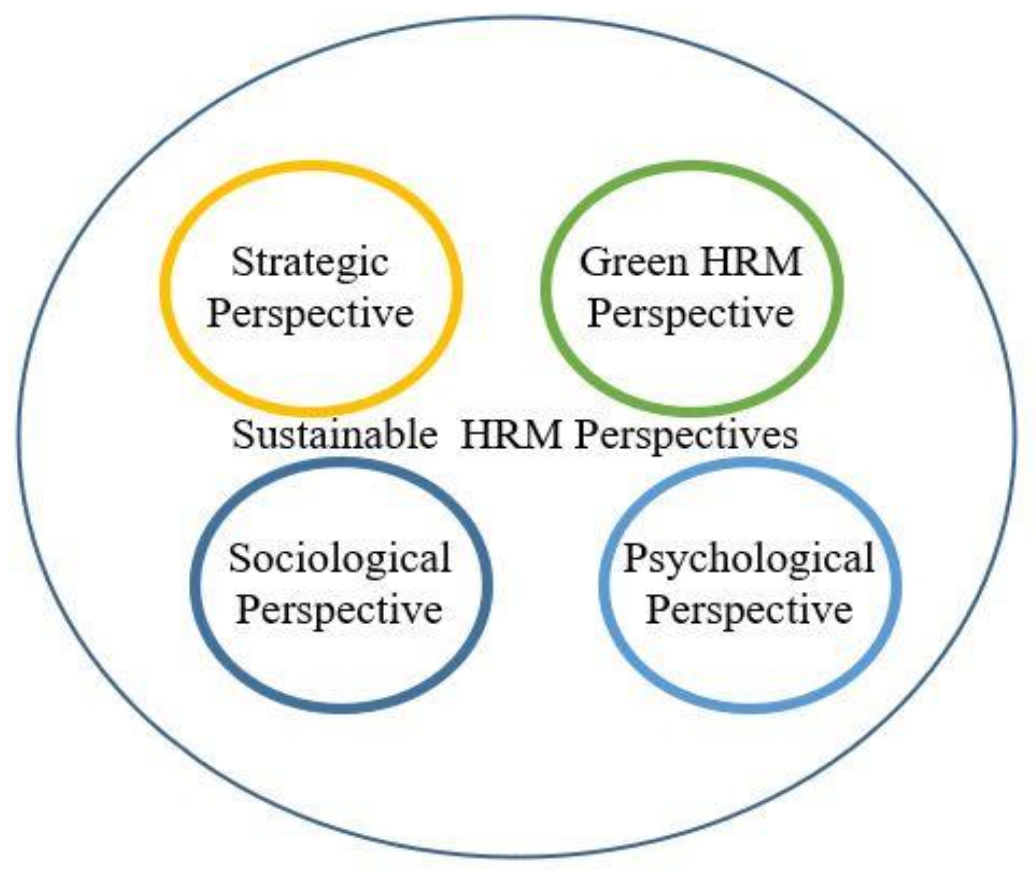

Figure 1. Sustainable HRM Perspectives. Source: Mazur (2015).

Green HRM is a contemporary perspective based on sustainable HRM, which links HRM functions with businesses' environmental objectives, such as green recruitment, training and development, green performance appraisal, and rewards [32]. Green HRM is a much more recent development in scholarly research and comprises sustainable HRM as a key component. It contends that organizations should align their processes to help resolve environmental problems. Table 1 summarizes the major studies made on green HRM 
practices, based on a review of the literature. Most used three main green HRM practices; these being (i) green recruitment and selection, (ii) green training and development, and (iii) green performance assessment and rewards. However, some research also used green employee relationships and green engagement to represent HRM practices [32].

Table 1. Green HRM Major Practices in the Literature.

\begin{tabular}{|c|c|c|c|c|c|}
\hline Authors & $\begin{array}{c}\text { Green } \\
\text { Recruitment } \\
\text { and Selection }\end{array}$ & $\begin{array}{c}\text { Green } \\
\text { Training and } \\
\text { Development }\end{array}$ & $\begin{array}{l}\text { Green Performance } \\
\text { Assessment and } \\
\text { Rewards }\end{array}$ & $\begin{array}{c}\text { Green } \\
\text { Employee } \\
\text { Relations }\end{array}$ & $\begin{array}{c}\text { Green } \\
\text { Employee } \\
\text { Engagement }\end{array}$ \\
\hline Jackson et al. [33] & $\sqrt{ }$ & $\sqrt{ }$ & $\sqrt{ }$ & & \\
\hline Jabbour et al. [34] & $\sqrt{ }$ & $\sqrt{ }$ & $\sqrt{ }$ & & \\
\hline Jackson and Seo [35] & $\sqrt{ }$ & $\sqrt{ }$ & $\sqrt{ }$ & & \\
\hline Stringer [36] & $\sqrt{ }$ & & & & \\
\hline Garavan and McGuire [37] & $\sqrt{ }$ & $\sqrt{ }$ & $\sqrt{ }$ & & \\
\hline Liebowitz [38] & & $\sqrt{ }$ & & & \\
\hline Delmas and Pekovic [39] & & $\sqrt{ }$ & & & \\
\hline Govindarajulu and Daily [40] & & $\sqrt{ }$ & $\sqrt{ }$ & & \\
\hline Daily et al. [41] & & $\sqrt{ }$ & $\sqrt{ }$ & & \\
\hline Fernández et al. [42] & & $\sqrt{ }$ & $\sqrt{ }$ & & \\
\hline Phillips [43] & $\sqrt{ }$ & & & & \\
\hline [36] & $\sqrt{ }$ & & & & \\
\hline Jabbour et al. [44] & & $\sqrt{ }$ & & & \\
\hline Ji et al. [45] & & $\sqrt{ }$ & & & \\
\hline Mandip [46] & & $\sqrt{ }$ & $\sqrt{ }$ & & \\
\hline Wagner [47] & $\sqrt{ }$ & & & & \\
\hline Renwick et al. [48] & $\sqrt{ }$ & $\sqrt{ }$ & $\sqrt{ }$ & $\sqrt{ }$ & \\
\hline Renwick, Redman and Maguire [32] & $\sqrt{ }$ & $\sqrt{ }$ & $\sqrt{ }$ & $\sqrt{ }$ & $\sqrt{ }$ \\
\hline Paillé et al. [49] & $\sqrt{ }$ & $\sqrt{ }$ & $\sqrt{ }$ & & \\
\hline Zibarras and Coan [50] & $\sqrt{ }$ & $\sqrt{ }$ & $\sqrt{ }$ & & \\
\hline Ahmad [51] & $\sqrt{ }$ & $\sqrt{ }$ & $\sqrt{ }$ & $\sqrt{ }$ & \\
\hline Jabbour and de Sousa Jabbour [52] & $\sqrt{ }$ & $\sqrt{ }$ & $\sqrt{ }$ & & \\
\hline Guerci and Carollo [53] & $\sqrt{ }$ & $\sqrt{ }$ & $\sqrt{ }$ & & \\
\hline Haddock-Millar et al. [54] & & & & & $\sqrt{ }$ \\
\hline O'Donohue and Torugsa [55] & $\sqrt{ }$ & $\sqrt{ }$ & $\sqrt{ }$ & & $\sqrt{ }$ \\
\hline Gholami et al. [56] & $\sqrt{ }$ & $\sqrt{ }$ & $\sqrt{ }$ & & $\sqrt{ }$ \\
\hline Tang et al. [57] & $\sqrt{ }$ & $\sqrt{ }$ & $\sqrt{ }$ & & \\
\hline Cheema and Javed [58] & $\sqrt{ }$ & & $\sqrt{ }$ & & \\
\hline Wehrmeyer [59] & $\sqrt{ }$ & $\sqrt{ }$ & $\sqrt{ }$ & & \\
\hline Milliman and Clair [60] & & & $\sqrt{ }$ & & \\
\hline Zaid et al. [61] & $\sqrt{ }$ & $\sqrt{ }$ & $\sqrt{ }$ & & \\
\hline Kim et al. [62] & $\sqrt{ }$ & $\sqrt{ }$ & $\sqrt{ }$ & & \\
\hline Ojo and Raman [8] & $\sqrt{ }$ & $\sqrt{ }$ & $\sqrt{ }$ & & $\sqrt{ }$ \\
\hline Saeed et al. [63] & $\sqrt{ }$ & $\sqrt{ }$ & $\sqrt{ }$ & & \\
\hline Pham et al. [64] & & $\sqrt{ }$ & $\sqrt{ }$ & & $\sqrt{ }$ \\
\hline
\end{tabular}


Table 1. Cont.

\begin{tabular}{|c|c|c|c|c|c|}
\hline Authors & $\begin{array}{c}\text { Green } \\
\text { Recruitment } \\
\text { and Selection }\end{array}$ & $\begin{array}{c}\text { Green } \\
\text { Training and } \\
\text { Development }\end{array}$ & $\begin{array}{c}\text { Green Performance } \\
\text { Assessment and } \\
\text { Rewards }\end{array}$ & $\begin{array}{c}\text { Green } \\
\text { Employee } \\
\text { Relations }\end{array}$ & $\begin{array}{c}\text { Green } \\
\text { Employee } \\
\text { Engagement }\end{array}$ \\
\hline Mariappanadar [65] & $\sqrt{ }$ & $\sqrt{ }$ & $\sqrt{ }$ & $\sqrt{ }$ & $\sqrt{ }$ \\
\hline Islam et al. [66] & $\sqrt{ }$ & $\sqrt{ }$ & $\sqrt{ }$ & & \\
\hline Hameed et al. [67] & $\sqrt{ }$ & $\sqrt{ }$ & $\sqrt{ }$ & & \\
\hline Mousa and Othman [68] & $\sqrt{ }$ & $\sqrt{ }$ & $\sqrt{ }$ & & $\sqrt{ }$ \\
\hline $\begin{array}{l}\text { Khan, Bhatti, Obaid, Sami, and } \\
\text { Ullah [27] }\end{array}$ & $\sqrt{ }$ & $\sqrt{ }$ & $\sqrt{ }$ & & \\
\hline $\begin{array}{c}\text { Khan, Wu, Saufi, Sabri, and } \\
\text { Shah [16] }\end{array}$ & $\sqrt{ }$ & $\sqrt{ }$ & $\sqrt{ }$ & & \\
\hline Khan, Saufi, and Obaid [28] & $\sqrt{ }$ & $\sqrt{ }$ & $\sqrt{ }$ & & \\
\hline
\end{tabular}

\subsection{Organizational Citizenship Behavior for the Environment (OCBE)}

Existing scholarship classifies pro-environmental behavior (PEB) into two categories, based on the differences between the kinds of tasks that organizations and their employees perform. These include activities that differentiate tasks based on prescribed and voluntary actions. In the first stream of literature, the prescribed tasks perspective refers to behaviors that are officially and organizationally mandated. These include EMS and policies dealing with the environment [69]. Under efforts geared towards prescribed tasks, company management encourages employees to take a voluntary initiative to engage in formal talks on how to implement environment-sensitive practices. The second stream of literature is rooted in the industrial and organizational (IO) psychology perspective. The attention of researchers here is on voluntary and discretionary behaviors [70]. Organizational citizenship behavior for the environment (OCBE) involves discretionary efforts and behaviors and has crucial implications for management. According to Organ [71], OCB is expressed as "an individual behavior that is discretionary, not directly or explicitly recognized by the formal reward system, and that in the aggregate promotes the organization's effective functioning." According to this definition, employees have the freedom to engage or otherwise in environment-related programs [71]. Other research revealed that OCBE pre-dominantly represents voluntary actions of staff and their motivation to take up environmental initiatives [72,73]. However, the entire PEB is not discretionary, since $15-30 \%$ of such efforts are officially prescribed. The analysis comprised 1299 critical incidents; they showed both positive and negative behaviors. As shown in Figure 2, approximately $70 \%$ to $85 \%$ of environmental behaviors can be categorized as OCBE. Although they are discretionary, they are pivotal for encouraging corporate greening to foster sustainable business performance $[14,25]$. It is therefore vital to explore the key themes of OCBE and explain how its dimensions function in SP. 


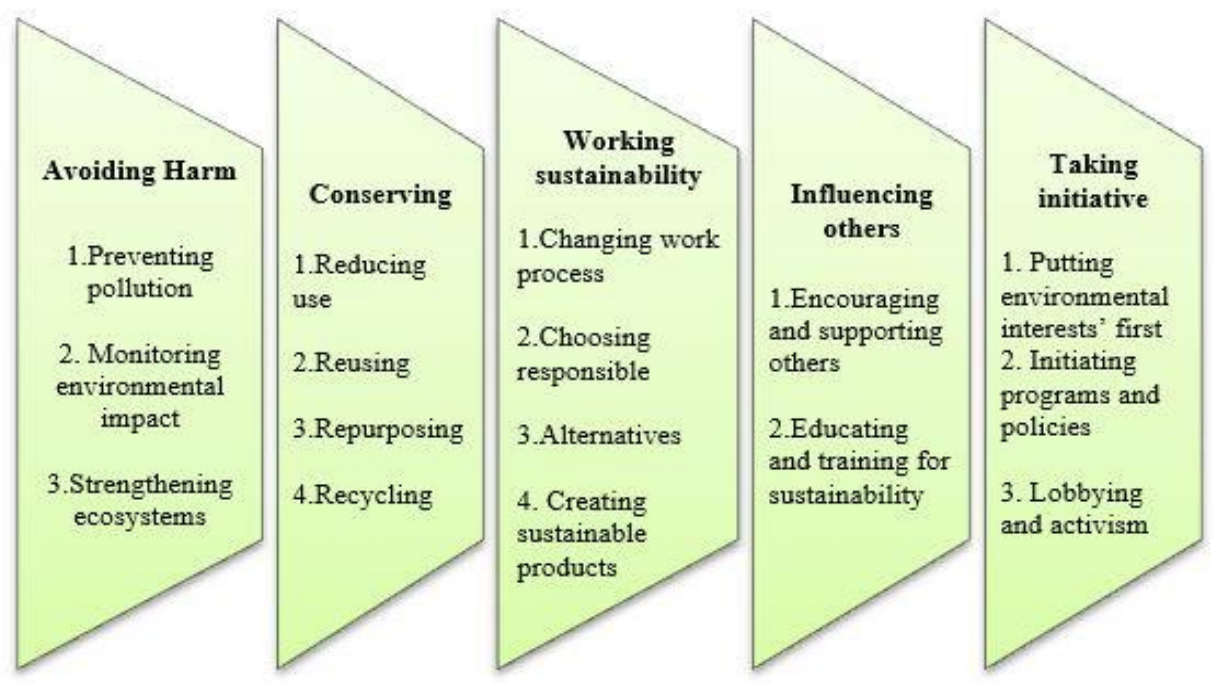

Figure 2. Five green taxonomies of pro-environmental behavior. Source: Ones and Dilchert (2012).

\subsection{Environmental Management System (EMS)}

'Our Common Future' (also known as The Brundtland Report) was a seminal report published in 1987 by the United Nations [74]. This ground-breaking document provided novel insights for effective environmental management and decision support systems. More than two decades later, the International Organization for Standardization (ISO), in collaboration with the International Electrotechnical Commission (IEC), organized what became known as the 'Earth Summit' held at Rio de Janeiro in 1992, to develop environmental standards [75]. The ISO and IEC allocated a committee with the task of evaluating and managing the development of an EMS [76]. The year 1996 witnessed the birth of the very first EMS-ISO14001, which was refined in later years, such as in 2000 and 2004. Its three key features, as described by the official website of the ISO are: (1) it helps companies minimize the pollution caused by their practices on the environment by identifying eco-friendly initiatives and better production processes; (2) EMS is systematic, and its implementation increases the efficiency in achieving eco-friendly objectives; and (3) the EMS helps improve the environmental performance of organizations continuously. In short, EMS ISO14001 gives a competitive advantage, so that the management teams of corporations actually implement better processes that foster environmental sustainability [77]. Other studies have examined the role of EMS from different perspectives, e.g., EMS motivations [78], adoption or implementation [79], performance standards [80], and the level of EMS diffusion impacting on performance [81]. Based on these perspectives, we conclude that EMS ISO14001 certified manufacturing companies can manage their environmental/economic performance more efficiently.

\subsection{Sustainable Performance}

The concept of corporate sustainability is based on the triple bottom line (TBL) framework of performance [82]. The TBL framework consists of three dimensions: economic, social, and environmental, leading to sustainability. Differently, some studies have revealed limitations and shortcomings concerning TBL measurement, non-systematic approaches, and compliance mechanisms [83]. The TBL approach can measure sustainable performance (SP). SP offers a framework that integrates business performance on the basis of social, environmental, and economic dimensions [84]. SP is a dynamic concept, as it focuses on creating synergies between social, economic, and environmental variables $[85,86]$. The TBL is conceptualized here as deeply embedding these three elements, which are measurable, as illustrated in Figure 3. Firms can only achieve excellent TBL performance if they are well-versed in managing the intricacies and variabilities that exist amongst these three elements. 


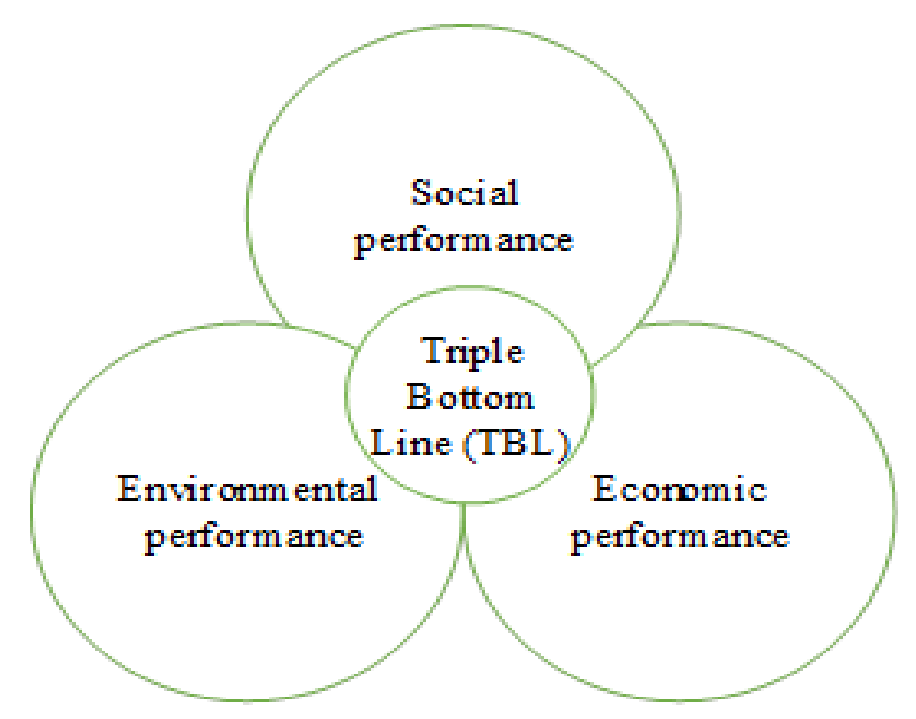

Figure 3. Triple Bottom Line (TBL) Performance. Source: Elkington (1994).

\subsection{Research Objectives}

The research objectives make it possible to explain the key questions that are to be explored [87]. Research objectives are constructed in light of the questions being asked and leading to viable conclusions. The current study has four key objectives: (i) to explore the key themes of green HRM practices in explaining how SP works in manufacturing firms; (ii) to explore the key themes of OCBE to explain SP among manufacturing firms; (iii) to explore the key themes of EMS in explaining SP; and (iv) to assess the key themes of SP in relation to emerging themes of green HRM, EMS, and OCBE among manufacturing firms.

\section{Research Methods and Interpretivist Paradigm}

The research method provides a plan for investigating a problem. This paper employed a qualitative methodology based on an interpretivist approach to answer the research questions [88]. The interpretivist research paradigm originated in the hermeneutics approach devised by German researchers. The interpretivist paradigm seeks to investigate certain phenomena based on an understanding of 'the world of human experience'. This approach assumes that reality is socially constructed. Researchers of this school of thought tend to rely on their own recognition, participants' views, situations, and observations. Usually, a study based on the interpretivist approach develops a theory inductively, and this paradigm provides a basis for qualitative studies [89]. Social constructivist researchers accept the presence of subjectivity when conducting a research inquiry. This means they are fully aware of their own personal, cultural, and historical biases and assumptions [88].

\subsection{Choosing a Research Approach}

The research design is mainly based on two critical approaches: i.e., deductive and inductive. Quantitative research uses a deductive approach, where the researcher develops a hypothesis based on an underlying theory, with the ultimate objective to corroborate a theory or theories. In contrast, qualitative research uses an inductive approach, which allows the researcher to develop a hypothesis from observations and interviews with the key objective of creating a theory based on data analysis. Qualitative research uses an inductive approach that allows the researcher to collect data through observations, case studies and interviews to create a theory-based qualitative data analysis $[88,90]$. The inductive approach is grounded in the interpretivist paradigm, which assumes that reality is socially constructed and subject to the researcher's own assumptions and those of the participants who are interviewed or surveyed (see Figure 4). The purpose of the current qualitative study was to explain the key themes that emerged from the thematic analysis. Consequently, in this qualitative study, the researcher looked for rich and meaningful 
data patterns concerning green HRM practices, OCBE, EMS, and SP using an inductive approach $[88,90]$.

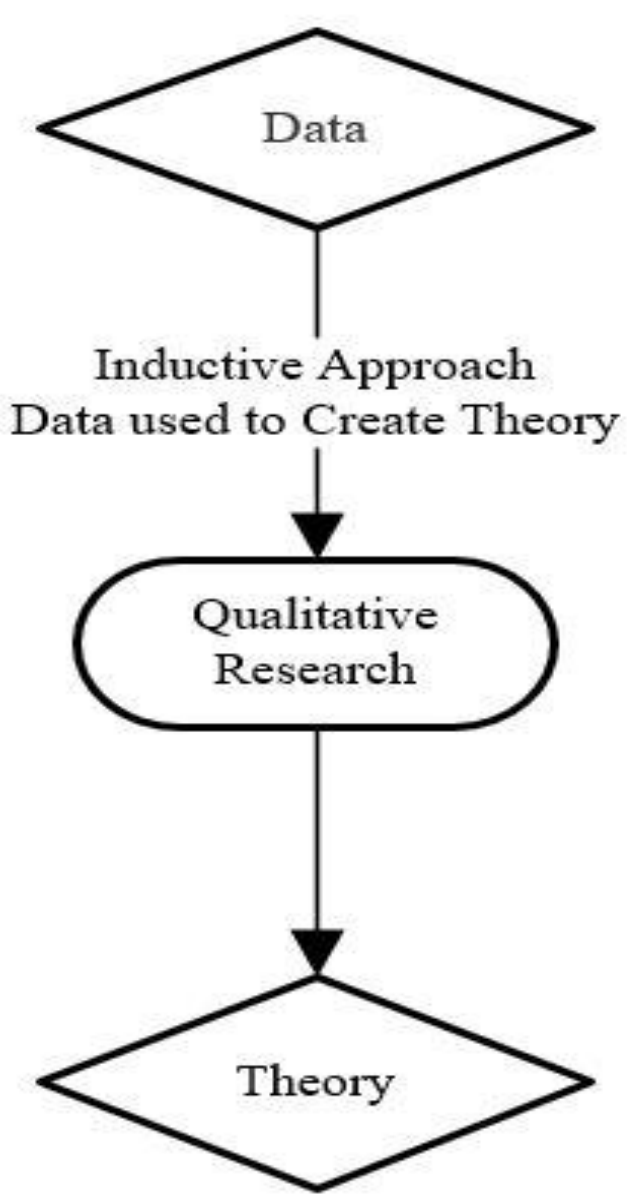

Figure 4. Inductive Approach in Qualitative Research. Source: Saunders et al. (2012).

\subsection{Rationale for Choosing a Qualitative Design}

A qualitative research design was employed in this study [91]. The existing literature highlights three significant challenges for the application of research methods in HRM: (1) longitudinal studies, (2) multi-method data or sources of information on HRM practices, and (3) mixed-method research designs [92,93]. Sustainable HRM has shortcomings in terms of quantitative and qualitative research. A substantial research gap exists in this topic, because there is not enough qualitative research on sustainable HRM and it can shape or guide business sustainability strategy. The literature has reported only a few comparative research studies on green HRM [54] because it is a relatively new area, and primarily theoretical and conceptual studies have been published [27,28,32]. Research on green HRM using qualitative methods has been carried out $[30,32,51-53,94,95]$. Quantitative analyses include the following: $[16,27,47,50,55,96,97]$. However, very few studies that use mixed method approaches in green HRM have been performed [28,34,98,99]. Furthermore, studies are very scarce on using a qualitative method in green HRM to explore the key themes of green HRM practices, organizational citizenship behavior for the environment (OCBE), and environmental management systems (EMS), and how they apply to sustainable performance (SP). This paper bridges this gap by employing a qualitative design using a thematic network approach. 


\subsection{Target Population}

A total of 492 ISO14001-certified Malaysian manufacturing firms were registered in the 49th edition of the Federation of Malaysian Manufacturers (FMM) in 2018. These firms are in the northern, central, and southern regions of Peninsular Malaysia, as illustrated in Figure 5. The majority are in the central region, i.e., Kuala Lumpur, Selangor, and the southern region, mainly in Johor and Malacca. The manufacturing subcategories include food; beverages and tobacco; chemicals, including petroleum; fabricated metals; electrical and electronics; machinery; plastic; transport; rubber; and others [100].

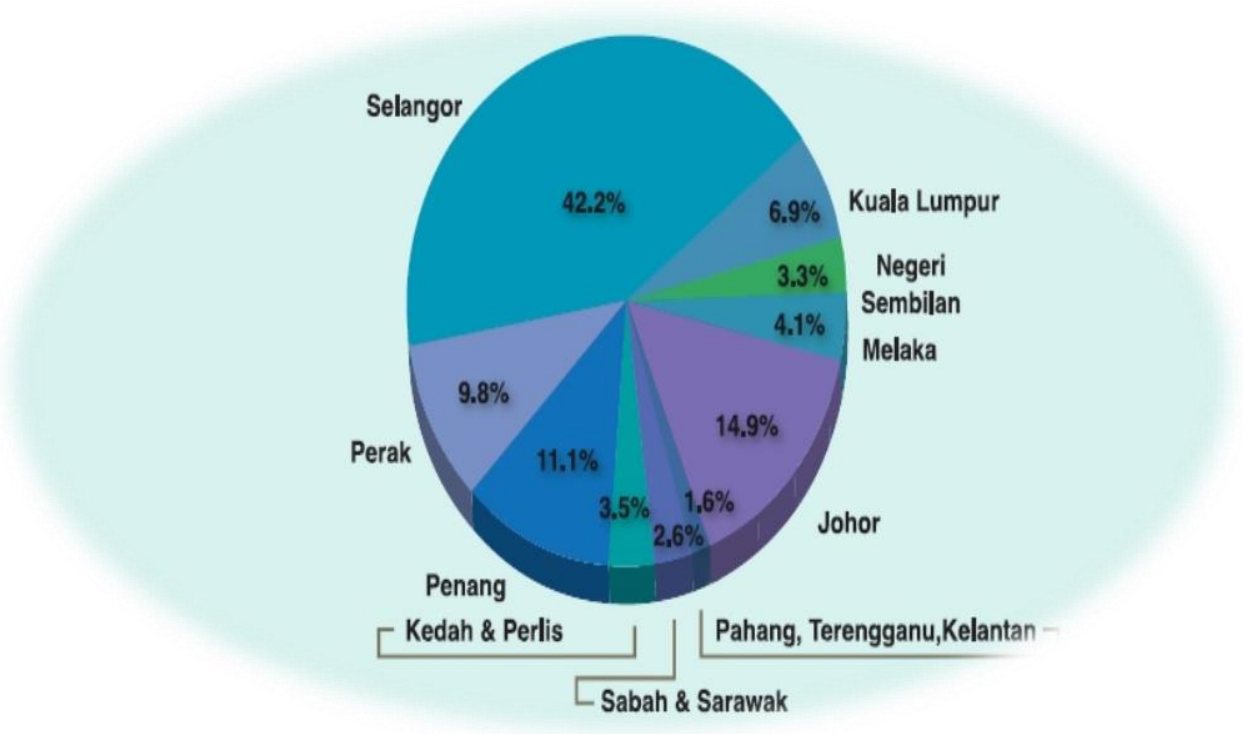

Figure 5. Manufacturing Companies by State. Source: FMM Directory (2018, p. 33a).

\subsection{Application of Qualitative Design}

Figure 6 illustrates a flow chart of the qualitative design, which is composed of several sequential steps. The first researcher selected the inductive realism approach. Next, the interview protocol was designed based on the research questions using the interview protocol refinement (IPR) framework. Semi-structured interviews were devised to collect the relevant qualitative data. Based on the saturation principle, face-to-face interviews were conducted with nine HRM managers of ISO14001-certified Malaysian manufacturing businesses. Finally, the transcribed data were imported into NVivo 12 for coding and analysis. All processes strictly followed ethical considerations, ensuring research credibility, integrity, and transferability.

The first section of the interview protocol comprises demographic information about participants and company background. In this section, the interviewer asks basic questions about the participant's name (ID), age, gender, type of manager, years of experience, and type of manufacturing firm. The second section comprises three main interview questions and sub-probing questions. The complete interview questions are documented in Appendix A. 


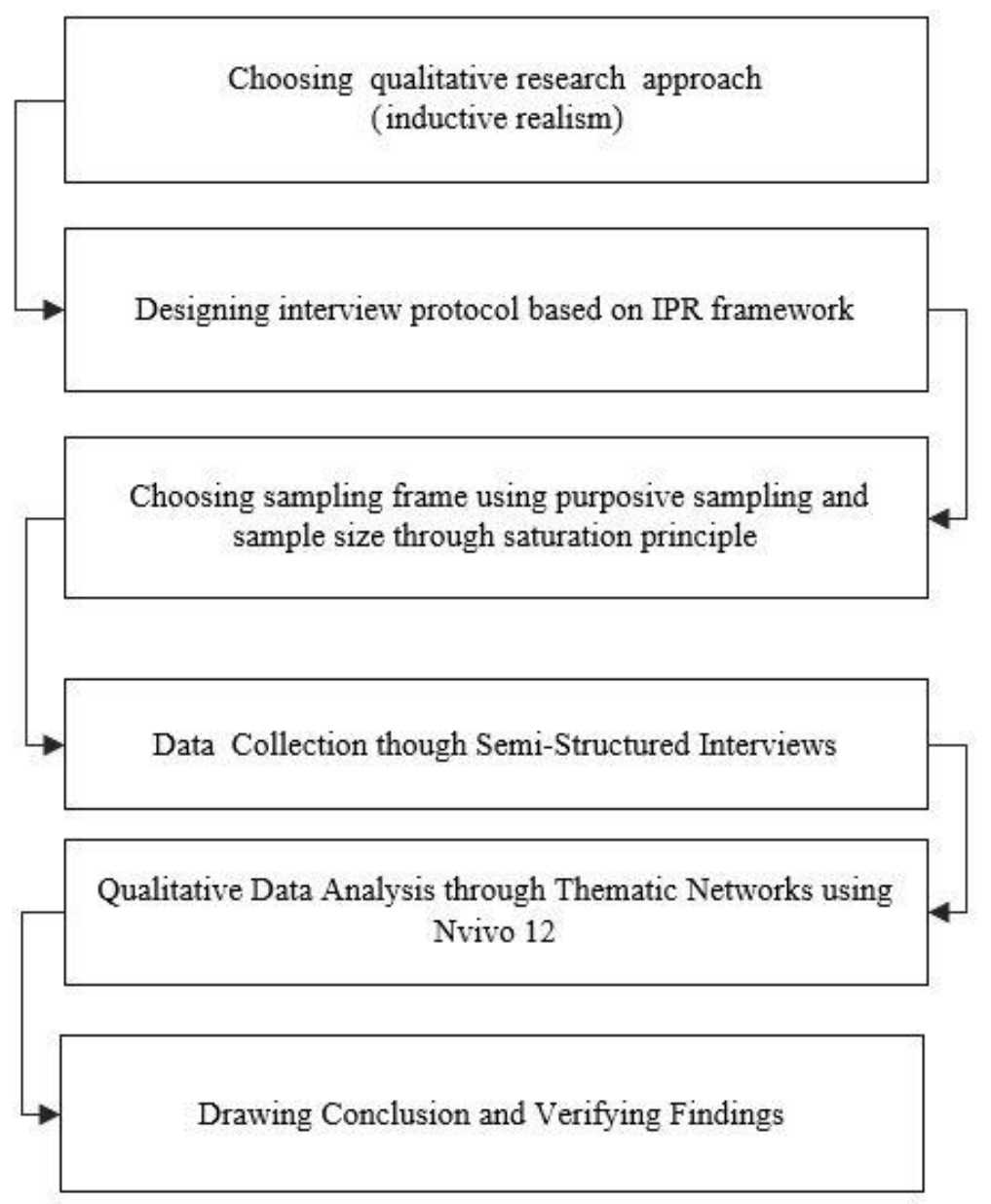

Figure 6. Qualitative Research Design protocol. Source: Current study.

\subsection{Designing the Interview Protocol}

Scholars have long discussed the importance of interviews as a tool for data collection in qualitative research. Significant attention has been paid to the procedures and significance of carrying out interviews. The critical points discussed include, but are not limited to, the appropriate circumstances in which the interviews are conducted, interviewerinterviewee trust issues, decisions regarding the location and length of each interview, the sequence of interview questions, the quality of an interview, and the clarity of the analysis of the interviews [88,90]. Based on qualitative research done by Castillo-Montoya [101], this study used a systematic framework for designing and refining the interview protocols. The interview protocol refinement (IPR) framework comprises four phases (see Table 2). In phase 1, the interview protocol matrix was created by mapping and aligning the interview questions with the research questions. In phase 2, the researcher conversed with qualitative methodology experts to scrutinize the wording of questions, to ensure they made sense. Subsequently, in phase 3, feedback from experts was obtained on the interview protocol, and based on this feedback, the questions were reviewed and reworded to ensure their clarity, simplicity, and answerability.

Upon completion of the three phases, an interview protocol was pilot tested in phase 4, and this incorporated a small sample of five HRM managers. This small size was chosen due to the constraints of time, money, and access [102]. The objective of the pilot test was to confirm the coverage and relevance of the content. A mutual consensus was reached by the qualitative researchers to employ the IPR framework; as this enhances the reliability of a research instrument, which in the present study is the interview protocol [103]. 
Table 2. Interview Protocol Refinement (IPR) Framework.

\begin{tabular}{cc}
\hline Phases & Rational \\
\hline $\begin{array}{c}\text { Phase 1: Ensuring interview questions align with research } \\
\text { questions }\end{array}$ & $\begin{array}{c}\text { To create an interview protocol matrix to map the interview } \\
\text { questions against the research questions }\end{array}$ \\
\hline Phase 2: Constructing an inquiry-based conversation & $\begin{array}{c}\text { To construct an interview protocol that balances inquiry with } \\
\text { conversation }\end{array}$ \\
\hline Phase 3: Receiving feedback on interview protocol & $\begin{array}{c}\text { To obtain feedback on interview protocol (possible activities } \\
\text { include close reading and think-aloud activities) }\end{array}$ \\
\hline Phase 4: Piloting the interview protocol & To pilot the interview protocol with a small sample \\
\hline
\end{tabular}

Source: Castillo-Montoya (2016).

\subsection{Sampling Frame for Semi-Structured Interviews}

The literature discussed the importance of selecting relevant interview participants, who are voluntarily willing to share in-depth and sometimes confidential information. The purposive sampling technique is suitable for choosing respondents for qualitative studies using the interviews as a data collection tool $[88,104]$. This technique serves to select the participants, units, or cases 'based on a specific purpose rather than random selection' [105]. Participants in the current study were carefully chosen using the following criteria: (i) should have expert knowledge about the phenomenon being investigated; (ii) willingness to voluntarily take part in this research; and (iii) can produce the relevant and desired information [106].

\subsection{Sample Size for Semi-Structured Interviews}

Generally, the sample size in qualitative studies is small, since the objective is an in-depth exploration of the phenomenon or issue at hand. This is opposed to quantitative research design, where the objective of the study is a generalization based on numerical, statistical, or tabulated data. Every type of data and theme in qualitative research are essential. Therefore, the calculation of frequencies does not carry the same weight as it does in quantitative research. Although the sample size of qualitative research is generally between 5 and 50 respondents, this depends on the study's objectives [101,106]. It should be noted that the sample size in qualitative research cannot be pre-determined, so it is suggested that the data collection should continue until a 'saturation' point is reached. The data saturation point is reached when themes simply repeat themselves and no new information is received [88,107]. Using the purposive sampling technique, nine HRM managers working in ISO14001-certified Malaysian manufacturing firms registered with [100] were the interviewed study participants.

All the interviews were recorded and transcribed. The recordings were first carefully stored in an MP3 audio device. The researcher conducted nine semi-structured interviews to elicit rich data, in order to understand the experiences of the HRM managers of ISO140001-certified Malaysian manufacturing companies. Semi-structured interviews give an advantage to the researcher in terms of the overall structure and direction for interviewing those who take part. Simultaneously they make possible the flexibility of having open-ended questions in the interview protocol. Thus, semi-structured interviews serve as a data collection tool for two key reasons. First, they offer flexibility in exploring and probing participants about the phenomenon. Second, a semi-structured interview is best suited for highly specific issues [88,104].

\subsection{Qualitative Data Collection Processes and Analysis Approaches}

Once the researchers had designed a semi-structured interview protocol for qualitative data collection, the data collection processes were initiated after seeking permission from the prospective manufacturing firms. A formal consent letter from the Faculty of Management University Teknologi Malaysia (UTM) was sent to the respective companies. After the company granted official permission, a personal visit was made to confirm the 
interview date. The interview protocol was composed of five questions. The first two questions related to information about the study participant and company background, while the last three questions were based on green HRM practices, OCBE, and EMS, and SP (see Appendix A). Before conducting each interview, the researcher asked permission to record the discussion. Using an MP3 audio recorder helped the researcher concentrate on questioning and listening, which is essential for transcription purposes and analysis. The researcher asked some probing questions to obtain in-depth information on the themes of green HRM practices, OCBE, EMS, and SP [90].

On average, each interview lasted for around ninety (90) minutes. In total, nine HRM managers working at ISO-certified Malaysian manufacturing firms, in three main locations (Kuala Lumpur, Selangor, and Johor) were interviewed. Studies have been undertaken with qualitative data analysis approaches, and most explore, describe, and explain what their thematic data means [88,108]. Qualitative data were analyzed based on a four-step process proposed by [108]: (1) collecting the data, (2) displaying the data, (3) reducing the data to its essential features, and (4) drawing conclusions (see Figure 7).

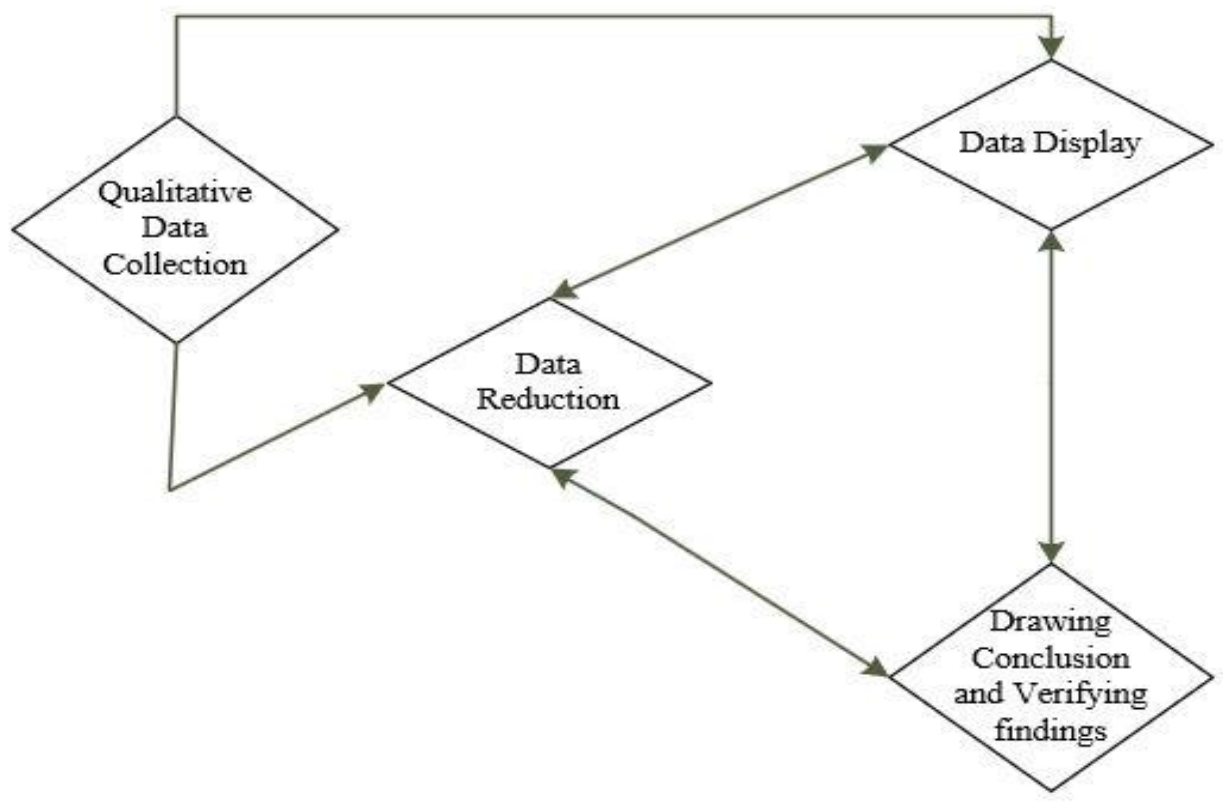

Figure 7. Qualitative Data Analysis. Source: (Miles and Huberman, 1994).

\subsection{Qualitative Data Analysis Using a Thematic Network}

The data was evaluated using the thematic network technique $[109,110]$. This delivers a graphical representation of the key themes, which are first extracted from the interview transcripts and then organized into a pictorial form as follows: (a) reduction of the text, (b) exploration of the text, and (c) integration of the text. This three-stage process followed an analysis of the data, as illustrated in Figure 8. The thematic analysis was conducted in six sequential steps. After doing this, the key themes of green HRM, OCBE, EMS, and SP emerged, as discussed in the results section. NVivo 12 uses the terminology of nodes, where the basic themes represent child nodes, and organizing and global themes are represented by parent nodes $[109,110]$. 


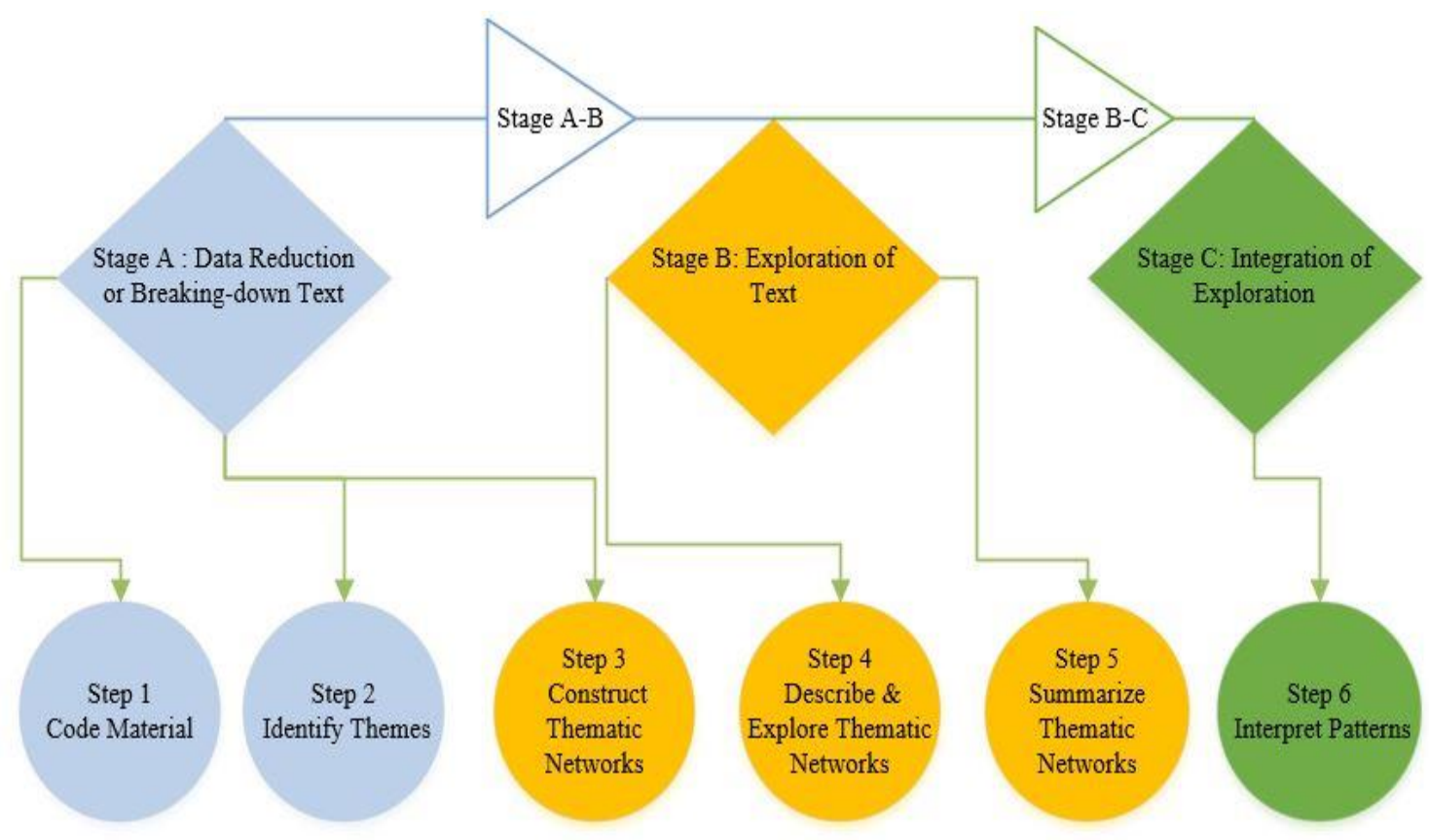

Figure 8. Steps in Thematic Network Analysis. Source: Current study.

\section{Results and Findings}

Qualitative data analysis was applied to the results and their interpretation via the thematic networks technique using NVivo 12. The analysis comprised several steps. Initially, the company background information was discussed. Table 3 displays the demographic information of the interview participants, in terms of their age, gender, current job role, company location, years of employment, and type of manufacturing firm. Of the nine participants, four managers were women and five were men. The age range was from mid-twenties to mid-forties, and the years worked were on average 5.3 years.

Table 3. Participant Demographics.

\begin{tabular}{ccccccc}
\hline ID & Name (*) $^{\text {Gender }}$ & Age & Company Location & Years of Employment & Type of Manufacturing Firm \\
\hline M01 & Manager A & Female & 27 & Kuala Lumpur & 4 years & Food, Beverages, and Tobacco \\
\hline M02 & Manager B & Male & 34 & Johor Bahru & 3 years & Chemical including petroleum \\
\hline M03 & Manager C & Female & 30 & Johor Bahru & 4 years & Electrical and electronics \\
\hline M04 & Manager D & Male & 31 & Selangor & 2 years & Fabricated metal \\
\hline M05 & Manager E & Female & 36 & Kuala Lumpur & 6 years & Machinery \\
\hline M06 & Manager F & Male & 29 & Selangor & 4 years & Plastic \\
\hline M07 & Manager G & Female & 33 & Johor Bahru & 5 years & Transport \\
\hline M08 & Manager H & Male & 45 & Johor Bahru & 10 years & Rubber \\
\hline M09 & Manager I & Male & 43 & Selangor & 9 years & Others \\
\hline
\end{tabular}

$\left(^{*}\right)$ Managers' names are pseudonyms to keep their anonymity in this study. Source: Current Study.

\subsection{Thematic Analysis}

This study employs a thematic network; a sophisticated technique employed in stages $[109,110]$. Once textual data was transposed into software, 'Word Frequency' analysis was first conducted to examine the frequency of words or terms used in the textual data. NVivo 12 produced a visual output known as a 'Word Cloud' and tabulated the statistics (see Table 4). The visual output 'Word Cloud' revealed that the most frequent words used 
were 'performance', 'green', 'environmental', 'green HRM', 'OCBE', 'sustainable', 'EMS (ISO14001)', 'practices', 'training', 'behavior', 'rewards', and 'employees'. A depiction of the 'Word Cloud' is shown in Figure 9.

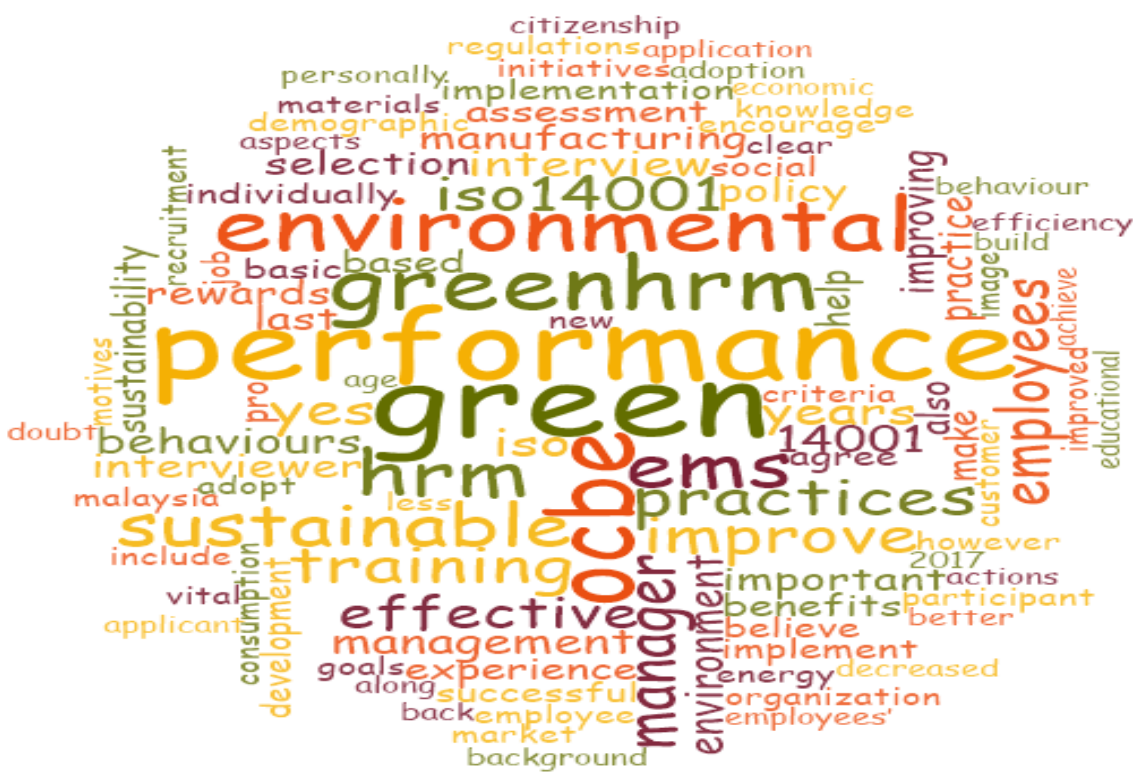

Figure 9. Word Cloud Nvivo 12 Output. Source: Current study.

Word frequency output included the count, percentage, and similar terms used in the text (see Table 4). The following word count estimates were documented: 'performance' (387) with 4.37\%; 'green' (297), with 3.36\%; 'environmental' (270), with $2.97 \%$; 'green-HRM' (225), with 2.54\%; 'OCBE' (261), with 2.46\%; 'sustainable' (216), with $2.37 \%$; 'EMS ISO14001' (225), with $2.28 \%$; 'practices' (207), with $2.24 \%$; 'training' (234), with $2.12 \%$; 'behavior' (162), with $1.83 \%$; 'rewards' (198), with $1.82 \%$; and 'employees' (153), with $1.73 \%$. This process eventually led to the second stage of analysis that served to generate the initial nodes.

Table 4. NVivo 12 Output Word Frequency.

\begin{tabular}{cccc}
\hline Word & Count & Weighted Percentage (\%) & Similar Words \\
\hline Performance & 387 & 4.37 & Operations, performance, sustainable performance \\
\hline Green & 297 & 3.36 & Green \\
\hline Environmental & 270 & 2.97 & Environmental, ecological, conservational \\
\hline Green-HRM & 225 & 2.54 & Green-HRM \\
\hline OCBE & 261 & 2.46 & OCBE \\
\hline Sustainable & 216 & 2.37 & Keeping, maintain, sustain, sustainability, sustainable \\
\hline EMS (ISO14001) & 225 & 2.28 & EMS (IS014001) \\
\hline Practices & 207 & 2.24 & Commitment, good, practices, use \\
\hline Training & 234 & 2.12 & Direct, education, educational, training, trainings \\
\hline Behavior & 162 & 1.83 & Behavior, behavior, behaviors \\
\hline Rewards & 198 & 1.82 & Reward, rewarded, rewards \\
\hline Employees & 153 & 1.73 & Employee, employees, employees'
\end{tabular}




\subsection{Creating Codes and Themes in NVivo 12}

Several initial thematic nodes were generated during the coding stage. Nodes were created through auto-coding in NVivo 12. This confirms how nodes were generated and connected with each other based on their relevance. Establishing groups of themes that were similar was the next stage. This involved the axial coding procedure, which was based on searching for and reviewing the themes. Axial coding required the researcher to rigorously analyze the data and establish what the themes should be. Based on the researcher's judgment, it was ensured that the generated themes accurately reflected the meaning of the text data and correctly represented the views and experiences of all participants [111,112].

The NVivo 12 interface enables the researcher to know how many participants shared information that reflected a particular theme. In NVivo 12, the 'sources' are the research materials, and in the present study this means the interview transcripts. The term 'references' refers to the number of coding references that are coded for a particular node. Fewer sources and coding references for a particular node is interpreted as indicating that either the theme is unimportant to participants or should be merged with some other theme. Alternatively, it should be kept aside for consideration, if needed at later stages of the study. The final coding process is called selective coding and involves the researcher seeking to identify the core variables or themes. In this study, these were identified as green HRM practices, organizational citizenship behavior for the environment (OCBE), and environmental management system (EMS), and how these factors explain sustainable performance (SP), as carried out by ISO14001-certified Malaysian manufacturing firms. Finally, the themes were classified according to their meaning, sources, and references [113]. Importantly, the first interview questions were (1) Does your company use green HRM practices to improve its sustainable performance? (2) Does your company implement EMS (ISO14001) to explain sustainable performance? (3) Do you believe that pro-environmental behavior, specifically OCBE, is vital for explaining the company's sustainable performance?

\subsection{Green HRM Practices and Sustainable Performance}

The first sub-probing interview question was: "In your opinion, what are the important green HRM practices that explain the sustainable performance of the company?" Based on thematic analysis, the three most important practices were (1) green recruitment and selection, (2) green training and development, and (3) green assessment and rewards. Child nodes for each theme are highlighted in Figure 10 below.

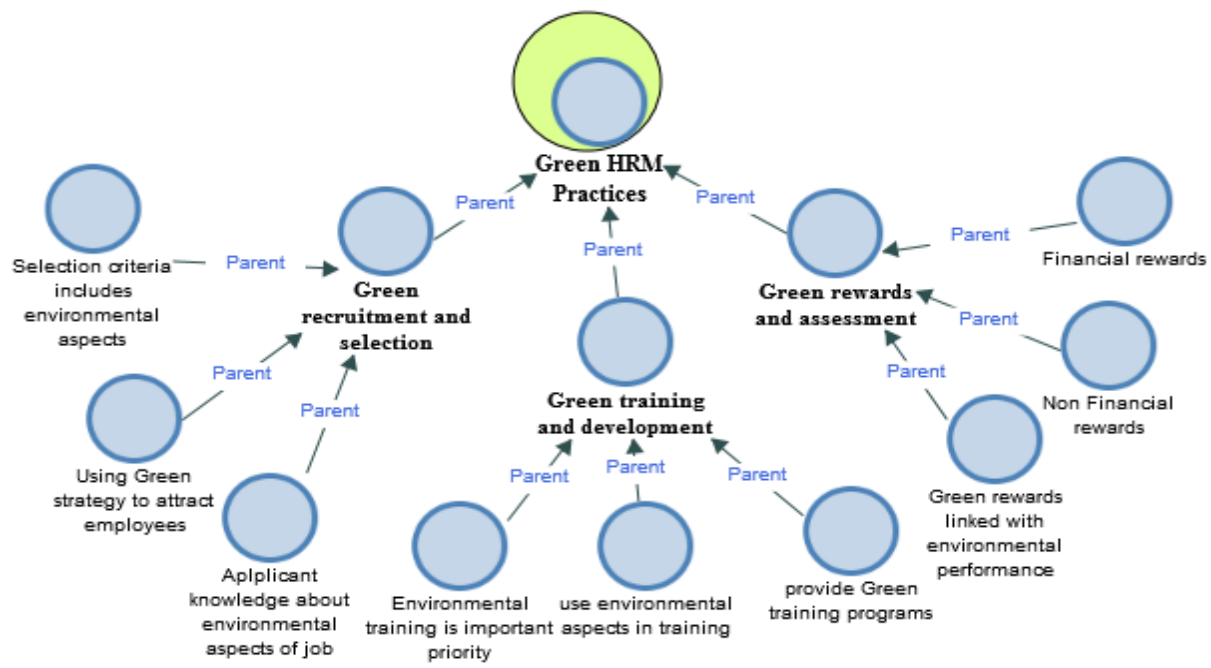

Figure 10. Green HRM Practices Themes. Source: Current study.

Green selection and recruitment themes were noted by eight participants, with thirteen coding references through the content analysis. Likewise, green training and development 
had seven sources and eleven coding references, and green assessment and rewards emerged from six sources, and eight coding references, as shown in Table 5. The first part of the thematic analysis explores green HRM practices that explain the sustainable performance of Malaysian manufacturing firms. The following section discusses the key motives and advantages of implementing an environmental management system (EMS) for the sustainable performance of ISO14001-certified Malaysian manufacturing firms.

Table 5. Green HRM Practices.

\begin{tabular}{cccc}
\hline Matrix Coding Query & $\begin{array}{c}\text { Green Selection } \\
\text { and Recruitment }\end{array}$ & $\begin{array}{c}\text { Green Training } \\
\text { and Development }\end{array}$ & $\begin{array}{c}\text { Green Rewards } \\
\text { and Assessment }\end{array}$ \\
\hline Sources & 08 & 07 & 06 \\
\hline Coding References (CR) & 13 & 11 & 08 \\
\hline Source: Current Study. & & &
\end{tabular}

\subsection{Environmental Management Systems and Sustainable Performance}

The second probing interview question was: "How do you describe the main motives and benefits of adopting EMS (ISO14001) in explaining sustainable performance"? Based on thematic analysis, three prominent themes emerged: (1) EMS ISO14001 is a reputable certification for manufacturing firms, (2) EMS generates key benefits, and (3) EMS key motives emerged. The child nodes for key motives reflected the business desire to meet customers' demands, comply with government policies and regulations, and improve operations in terms of efficiency and control. Likewise, child nodes for key adoption benefits included several social, economic, and environmental benefits. Outputs were generated through thematic analysis, as shown in Figure 11; three sub-themes serving as the child node from three main themes: EMS ISO14001, EMS key benefits, and motives. These all lead to a parent node, i.e., environmental management system.

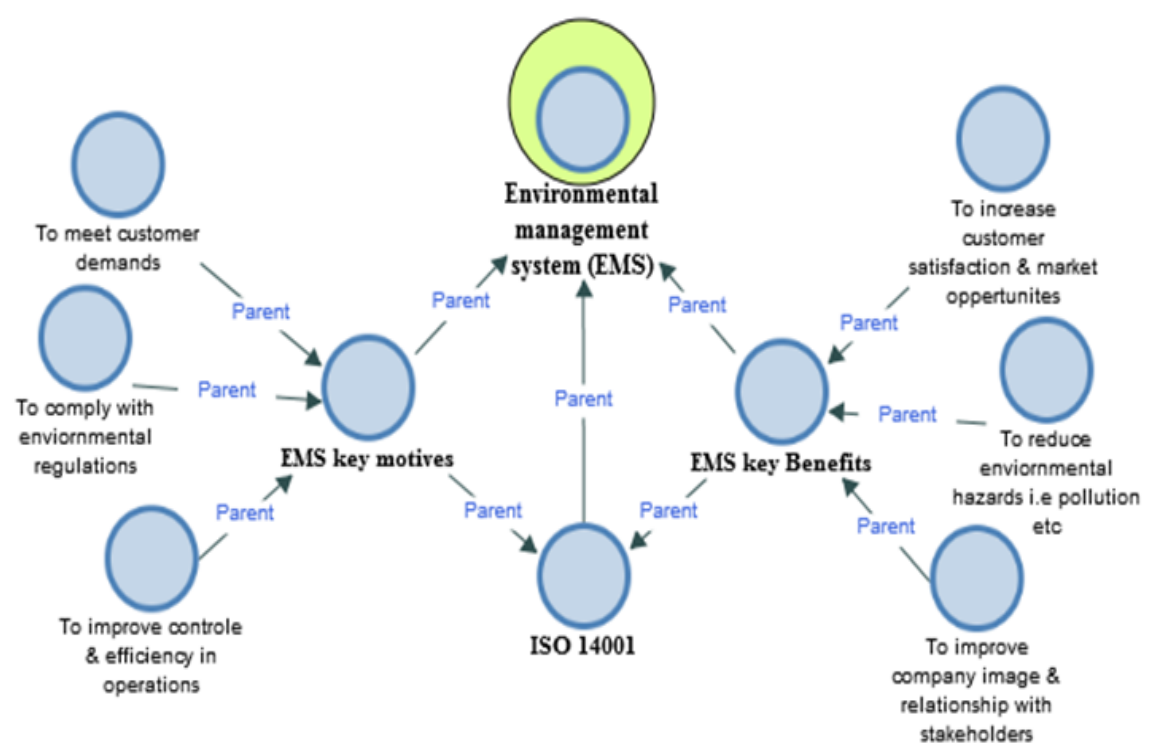

Figure 11. Environmental Management System (EMS) Themes. Source: Current study.

First, EMS ISO14001 was claimed to be important by nine participants, with thirty coding references throughout the content analysis. Likewise, EMS key motives had eight sources and seventeen coding references. EMS key benefits were noted in nine sources and twenty-seven coding references, as depicted in Table 6. The thematic analysis explores the adoption of EMS ISO14001, because certain EMS key motives and benefits explain the sustainable performance of ISO14001-certified Malaysian manufacturing firms. The next section discusses the vital role of OCBE in explaining sustainable performance. 
Table 6. Environmental Management System.

\begin{tabular}{lccc}
\hline Matrix Coding Query & EMS ISO 14001 & EMS Key Motives & Ems Key Benefits \\
\hline \multicolumn{1}{c}{ Sources } & 09 & 08 & 09 \\
\hline Coding References (CR) & 30 & 17 & 27 \\
\hline Source: Current Study. & & &
\end{tabular}

\subsection{OCBE and Sustainable Performance}

The third probing interview question was: "How does organizational citizenship behavior for the environment (OCBE) help your company to explain sustainable performance?" Based on the thematic analysis, the three prominent themes were as follows: (1) eco-helping behavior, (2) eco-initiatives behavior, and (3) eco-civic engagement behavior. Child nodes for eco-helping behavior include (i) expressing ideas and opinions on environmental issues, (ii) a company helping employees to protect the environment, and (iii) employees being encouraged by the company to be more pro-environmental. As shown in Figure 12, the NVivo 12 output of thematic analysis explains the sub-themes of OCBE and their child nodes.

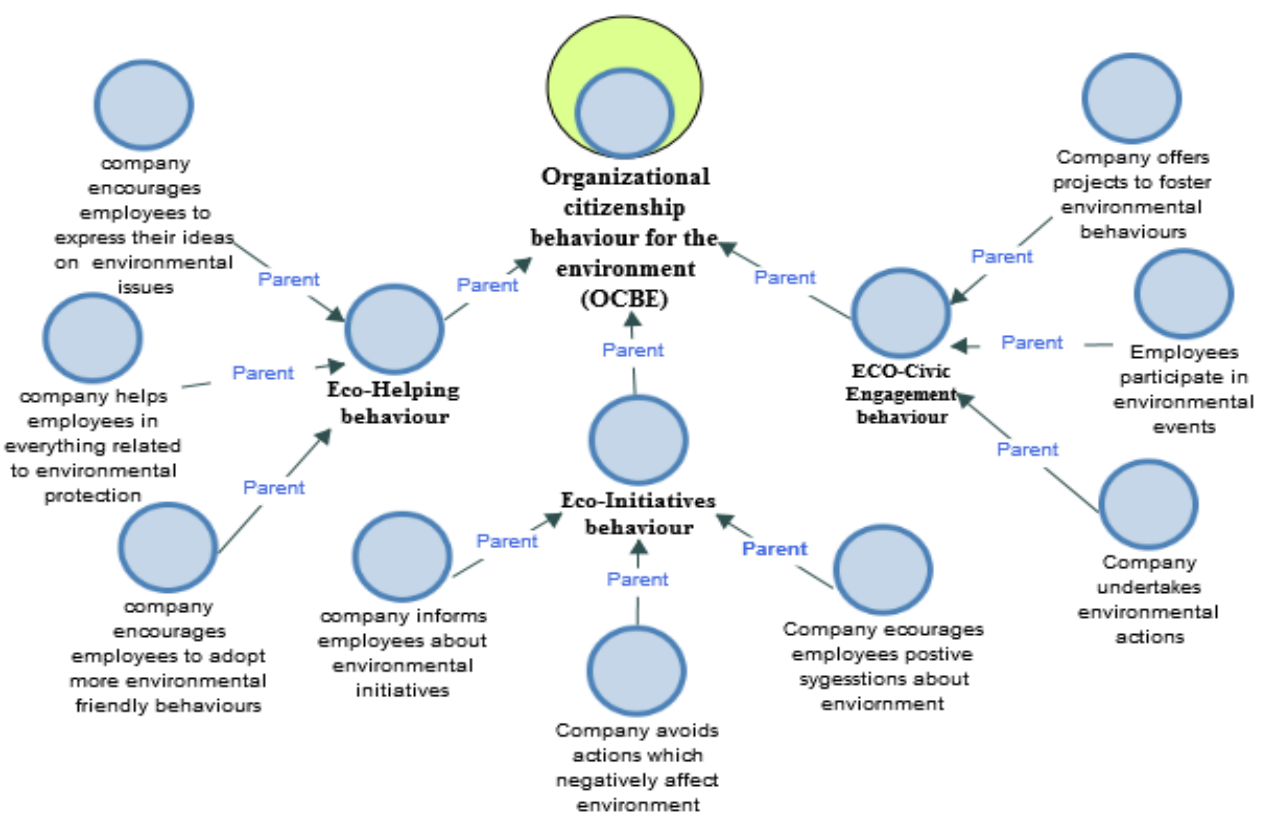

Figure 12. Organizational Citizenship Behavior for the Environment (OCBE) Themes. Source: Current study.

Child nodes for eco-initiative behavior are listed as follows: company keeps employees updated about environmental programs, avoid negative actions, and encourage employees' suggestions about what can be done about certain environmental issues. Similarly, child nodes for the eco-civic engagement behavior theme were employees' participation in events related to the environment, company actions to prevent damage being done to the environment, and staff volunteering in environmental projects. Table 7 presents the first sub-theme; (1) eco-helping behavior was noted by nine participants with ten coding references found in the content analysis. Likewise, (2) eco-initiatives behavior had eight sources and coding references, while, (3) eco-civic engagement behavior had seven sources and twelve coding references, respectively. The thematic analysis explores OCBE subthemes and their respective child nodes, seeking to explain the sustainable performance of ISO14001-certified Malaysian manufacturing firms. 
Table 7. Organizational Citizenship Behavior for the Environment (OCBE).

\begin{tabular}{cccc}
\hline Matrix Coding Query & $\begin{array}{c}\text { Eco-Helping } \\
\text { Behavior }\end{array}$ & $\begin{array}{c}\text { Eco-Initiatives } \\
\text { Behavior }\end{array}$ & $\begin{array}{c}\text { Eco-Civic-Engagement } \\
\text { Behavior }\end{array}$ \\
\hline Sources & 09 & 08 & 07 \\
\hline Coding References (CR) & 10 & 08 & 12 \\
\hline Source: Current Study. & &
\end{tabular}

\subsection{Assessment of Manufacturing Firms' Sustainable Performance}

The last part of the thematic analysis explores sub-themes and their respective child nodes, concerning sustainable performance as a central theme for the ISO14001-certified Malaysian manufacturing firms. Based on the thematic analysis, three key themes emerged: (1) economic performance, (2) environmental performance, and (3) social performance. As depicted in Figure 13 on the NVivo 12 output of thematic analysis, the sub-themes of sustainable performance and their child nodes were identified.

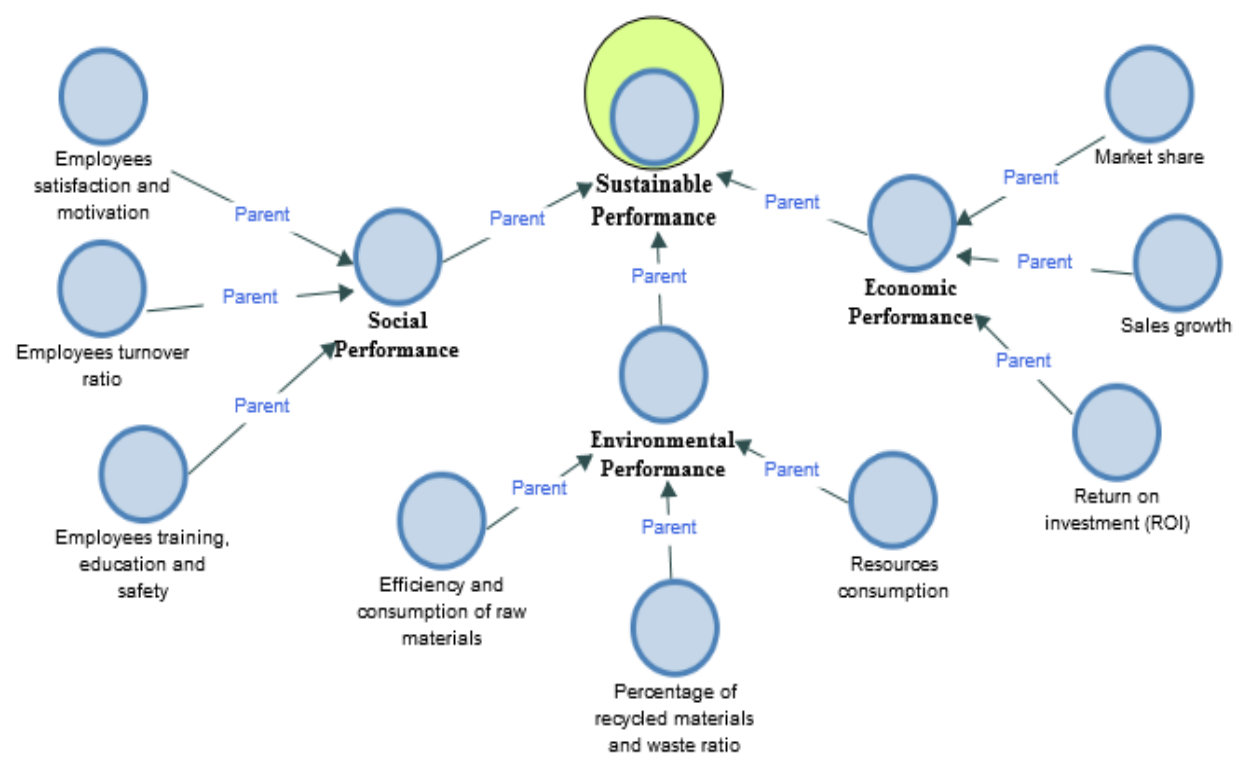

Figure 13. Assessment of Sustainable Performance. Source: Current study.

Table 8 presents themes; these are (1) economic performance, (2) environmental performance, and (3) social performance. The content analysis revealed that economic performance was noted by nine participants with eleven coding references. For the second, environmental performance had eight sources and twelve coding references, while the third, social performance, produced eight sources and ten coding references. Figure 14 summarizes the NVivo 12 outputs and explores all the major themes and their respective child nodes in this study.

Table 8. Sustainable Performance.

\begin{tabular}{cccc}
\hline Matrix Coding Query & $\begin{array}{c}\text { Economic } \\
\text { Performance }\end{array}$ & $\begin{array}{c}\text { Environmental } \\
\text { Performance }\end{array}$ & $\begin{array}{c}\text { Social } \\
\text { Performance }\end{array}$ \\
\hline Sources & 09 & 08 & 08 \\
\hline Coding References (CRs) & 11 & 12 & 10 \\
\hline
\end{tabular}




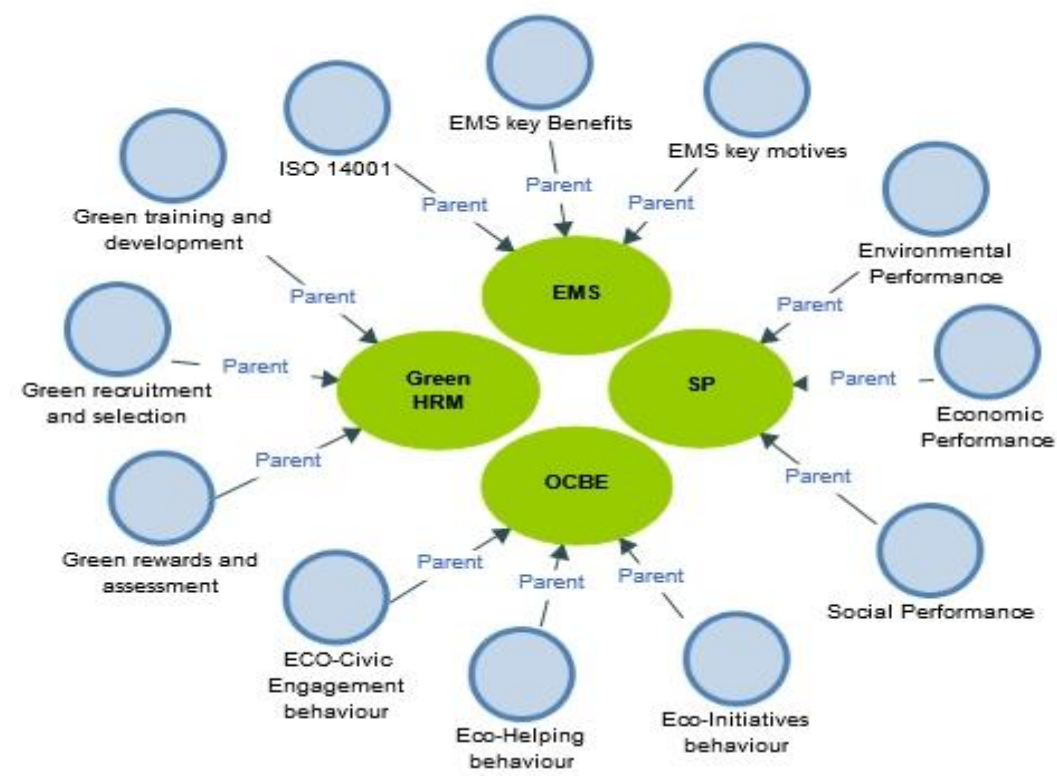

Figure 14. Summary of Thematic Analysis Models Source: Current study.

\section{Research Findings Discussion and Implications}

The qualitative data collected from nine HRM managers were analyzed through the thematic network technique using NVivo 12. Thematic network analysis explores basic and organizing themes within qualitative data. Four central (parent) themes, i.e., green HRM practices, organizational citizenship behavior for the environment (OCBE), environmental management system (EMS), and sustainable performance (SP) emerged. Green HRM was sub-divided into three further themes: (1) green recruitment and selection, (2) green training and development, and (3) green assessment and rewards. Subsequently, OCBE was also sub-divided into three organizing themes, these being: (1) eco-helping behavior, (2) eco-initiatives behavior, and (3) eco-civic engagement behavior. Likewise, EMS was sub-divided into three organizing themes, as follows: (1) ISO14001, (2) EMS key benefits, and (3) EMS key motives. In total, twelve organizing themes emerged in this study. Finally, each organizing theme (sibling node) resulted in three basic themes (child nodes); therefore, in total, twenty-seven basic themes (child nodes) existed.

Many participants confirmed that green assessment and rewards (GAR) could only be significant for sustainable performance when linked with a company's environmental objectives. One statement was, "Our company reward system is based on economic performance; manager interest lies only in those initiatives that enable cost reduction and improve economic value" (C). Most of the interviewed HRM managers (B, E, G, H, and I) confirmed that these behaviors are not covered by the company's reward management policy and likewise not rewarded by the company: "Our company is yet to design a reward system for encouraging OCBE" (G). The HRM managers of companies' (B) and (H) stated, respectively: "Our interest is only in measuring those environmental performances and initiatives that enable cost reduction" and "Our companies already introduced monetary incentives to motivate employees about environmental plans. However, it does not support environmental behavior, e.g., OCBE". It was stated by another respondent: "I hope our company should reward those employees who are committed to OCBE in the future" (E).

The majority of the HRM managers (B, E, F, G, and I) recognized that environmental training is used only for specific positions related to environmental issues in their company. One response was: "Our firm provides training only for technical aspects of EMS ISO14001 rather environmental training for all departments and employees" (B). Another HRM manager reported that "our company has decided to focus on environment-related skills in the selection process to avoid investing in environmental training" (E). Another respondent (G) stated, "The most critical factor for ISO14001, besides technical and procedural protocol, is the employees' involvement and 
participation. They need environmental awareness and training to ensure successful implementation of EMS". Based on these findings, companies should employ environmental training and development programs to implement EMS ISO14001 successfully. Notably, all the companies should provide extensive environment-related training to their employees for realizing sustainable performance. "Our firm has four offices across the country, all of them are ISO14001-certified. However, based on the FMM directory 2018, only 18\% of manufacturing firms have ISO14001 certification. There are several issues in adopting ISO14001, e.g., extensive documentation, cost, social and legal barriers" (I).

Green HRM practices are essential for companies to promote OCBE programs and encourage employees to work sustainably as an everyday behavior [63]. Green HRM practices are expressed and enacted through shared behavioral values. Such practices help a green organizational culture to develop and stimulate low-carbon-use actions [29]. Another advantage of green HRM practices is that they advance and spread the eco-friendly behaviors of staff, reflecting their workplace's behavior [62]. Ones and Dilchert [21] claimed that such behaviors are discretionary. For instance, $70-85 \%$ of employees were engaged in sustainable discretionary initiatives that were not part of a formal reward system. Since such behaviors are discretionary on behalf of the employees, it is worth mentioning that the term 'discretionary acts' signifies the idea of employees making decisions about sustainable practices voluntarily. Henceforth, OCBE should not be considered a component of formal responsibilities or be adhered to by all organizational employees. Previous studies have emphasized the crucial role of imparting training to the workforce regarding how all staff can embrace EMS ISO14001 [114].

Contrarily, the lack of such training results in deficient employee skills, leading to inadequate or non-existent sustainable practices [115]. Referring to Malaysian firms, they are confronting challenges in the implementation of EMS ISO14001. This challenge is deeply rooted in their inability to offer extensive training to employees, since such training is costly [116]. Existing research sheds light on several other factors, such as the requirements of extensive documentation and economic and social hurdles that make it difficult or not cost-effective for firms to adopt EMS ISO14001 [117]. Due to these problems, the implementation of EMS ISO14001 is extremely low, simply because the ISO certification of firms in Malaysia is very low. For instance, out of a total of 2561 manufacturers registered in the FMM 2018 directory, only 492 have this certification. Many factors can help encourage a high EMS ISO14001certification rate. These include, but are not limited to, (1) 'green rewards' that motivate all employees to show their commitment to environmentally responsible work practices, which fosters a climate of OCBE [52]; (2) efforts to become 'eco-champions' of green HRM strategies and values; and (3) efforts to get employees working as 'green teams'.

Findings obtained in this study demonstrate an urgent need for manufacturing firms to engage effectively in green HRM practices. Furthermore, to improve SP, they must adopt EMS ISO14001 and encourage OCBE. Eventually, the widespread adoption of green practices will end the disparity between economic and environmental performance $[97,116]$. Understanding green HRM practices is indispensable, so organizations must encourage their employees to engage in OCBE and environmental activities, such as EMS ISO14001 [4] To achieve greater employee participation in SP, support, involvement, and encouragement from management are highly important. Companies can facilitate the increased participation of employees in environmentally friendly practices by implementing green HRM practices through green selection and recruitment. These, however, only function well when the managers take their eco-friendly appraisals seriously [32]. The current qualitative study has some inherent limitations. The qualitative researcher used subjective data using semi-structured interviews, and personal experiences and knowledge shaped the observations and conclusions. Qualitative research requires thoughtful planning and skills to ensure the validity of all the data and results. The findings cannot be validated through quantitative or mathematical modeling alone, and the findings cannot be generalized to other contexts, due to the small sample size. 


\section{Conclusions}

Manufacturing organizations play a critical role in the country's economic growth. However, this comes with the cost of environmental issues. Likewise, sustainability is an equally important concern for Malaysian manufacturers, in order to achieve SP. Organizations should make an effort to achieve equal outcomes in the economic, environmental, and social domains. To achieve SP, the manufacturing firms should implement green HRM practices, adopt EMS ISO14001, and encourage OCBE to enhance SP. This research presents important recommendations for managers and their companies. Given this study's inherent limitations, future research can explore more relevant themes of SP, with a large sample employing mixed-method approaches. The findings are aligned with the environmental performance index (EPI), national policy on the environment (NEP), and compendium of environment statistics. The adoption of EMS is vital, and the ISO14001 certification level can be improved by making it mandatory for Malaysian manufacturers with effective environmental regulations and compliance [118].

Author Contributions: Conceptualization, N.U.K., and H.W.; methodology, G.Y.; software; validation, N.U.K.; formal analysis.; investigation, H.W.; resources, N.U.K.; data curation, N.U.K.; writing-original draft preparation, G.Y., N.N. and N.R.Z.; writing—review and editing; N.U.K.; project administration. All authors have read and agreed to the published version of the manuscript.

Funding: This research received no external funding.

Institutional Review Board Statement: Not applicable.

Informed Consent Statement: Not applicable.

Data Availability Statement: The data presented in this study are available on request from the corresponding author.

Conflicts of Interest: The authors declare no conflict of interest.

\section{Appendix A}

Table A1. Interview Protocol.

\begin{tabular}{|c|c|c|c|c|}
\hline Q. 1 & Participant ID & Gender & Position & $\begin{array}{c}\text { Years of } \\
\text { Employment }\end{array}$ \\
\hline Q. 2 & Type of Manufacturing Firm & Interview Duration & Interview Date & Type of Int \\
\hline \multirow{2}{*}{ Q. 3} & \multicolumn{4}{|l|}{ Interview Questions } \\
\hline & \multicolumn{4}{|c|}{ Does your company use Green HRM practices to improve sustainable performance? } \\
\hline Probing & \multicolumn{4}{|c|}{$\begin{array}{l}\text { If yes, in your opinion, what are the critical green HRM practices that can improve the sustainable performance of } \\
\text { the company? }\end{array}$} \\
\hline Questions & \multicolumn{4}{|c|}{$\begin{array}{l}\text { Do you think that individually, green selection and recruitment, green training and development, and green } \\
\text { assessment rewards practices are effective for improving sustainable performance? }\end{array}$} \\
\hline Q. 4 & \multicolumn{4}{|c|}{ Does your company implement EMS (ISO14001) to improve sustainable performance? } \\
\hline $\begin{array}{l}\text { Probing } \\
\text { Questions }\end{array}$ & $\begin{array}{l}\text { If yes, how do you describe tl } \\
\text { performance? } \\
\text { Do you believe that green HR } \\
\text { sustainable performance? } \\
\text { Do you think that individuall } \\
\text { assessment rewards practices }\end{array}$ & $\begin{array}{l}\text { main motives and benefits of adopting } \\
\text { A practices are essential for successfully in } \\
\text { green selection and recruitment, green tr } \\
\text { ead to effective EMS (ISO 14001) implem }\end{array}$ & $\begin{array}{l}\text { IS (ISO 14001) to i } \\
\text { ementing EMS (IS } \\
\text { ning and develop } \\
\text { tation? }\end{array}$ & $\begin{array}{l}\text { rove sustainable } \\
\text { 14001) in improving } \\
\text { nt, and green }\end{array}$ \\
\hline Q. 5 & \multicolumn{4}{|c|}{$\begin{array}{l}\text { Do you believe that pro-environmental behaviors, more specifically organizational citizenship behavior for the } \\
\text { environment (OCBE), are vital for improving the company's sustainable performance? }\end{array}$} \\
\hline $\begin{array}{l}\text { Probing } \\
\text { Questions }\end{array}$ & \multicolumn{4}{|c|}{$\begin{array}{l}\text { If yes, how does organizational citizenship behavior for the environment (OCBE) help your company to improve } \\
\text { sustainable performance? } \\
\text { What are the key types of OCBE? } \\
\text { Do you believe that individually, green selection and recruitment, green training and development, and green } \\
\text { assessment rewards practices can effectively foster OCBE? }\end{array}$} \\
\hline
\end{tabular}




\section{References}

1. Ahmad, S.; Wong, K.Y. Sustainability assessment in the manufacturing industry: A review of recent studies. Benchmarking Int. J. 2018, 25, 3162-3179. [CrossRef]

2. Yu, T.-K.; Lin, F.-Y.; Kao, K.-Y.; Chao, C.-M.; Yu, T.-Y. An innovative environmental citizen behavior model: Recycling intention as climate change mitigation strategies. J. Environ. Manag. 2019, 247, 499-508. [CrossRef]

3. Birol, F.; Wanner, B.; Kesicki, F.; Hood, C.; Baroni, M.; Bennett, S. World Energy Outlook Special Report: Energy and Climate Change; IEA: Paris, France, 2015.

4. Robertson, J.L.; Barling, J. Toward a new measure of organizational environmental citizenship behavior. J. Bus. Res. 2017, 75, 57-66. [CrossRef]

5. Khan, N.U.; Ahmed, A.; Khattak, A. Do organizational citizenship behavior for the environment predict triple bottom line performance in manufacturing firms? Bus. Process Manag. J. 2021, 27, 1033-1053. [CrossRef]

6. Ghazilla, R.A.R.; Sakundarini, N.; Abdul-Rashid, S.H.; Ayub, N.S.; Olugu, E.U.; Musa, S.N. Drivers and barriers analysis for green manufacturing practices in Malaysian SMEs: A preliminary findings. Procedia Cirp 2015, 26, 658-663. [CrossRef]

7. Sajan, M.; Shalij, P.; Ramesh, A. Lean manufacturing practices in Indian manufacturing SMEs and their effect on sustainability performance. J. Manuf. Technol. Manag. 2017, 28, 772-793.

8. Ojo, A.O.; Raman, M. Role of Green HRM practices in employees' pro-environmental IT Practices. In Proceedings of the World Conference on Information Systems and Technologies, Galicia, Spain, 16-19 April 2019; pp. 678-688.

9. Khan, N.U.; Saufi, R.A.; Ahmed, A. Antecedents of organizational citizenship behavior towards the environment in manufacturing organizations: Using a structural equation modeling approach. Bus. Process Manag. J. 2021, 27, 1054-1087. [CrossRef]

10. Fuzi, N.M.; Habidin, N.F.; Janudin, S.E.; Ong, S.Y.Y. Environmental management accounting practices, management system, and performance. Int. J. Qual. Reliab. Manag. 2019, 18, 120-136. [CrossRef]

11. MITI. MITI Weekly Bulletin. Available online: https://www.miti.gov.my/index.php/pages/view/3060 (accessed on 30 August 2019).

12. Ikram, M.; Zhou, P.; Shah, S.; Liu, G. Do environmental management systems help improve corporate sustainable development? Evidence from manufacturing companies in Pakistan. J. Clean. Prod. 2019, 226, 628-641. [CrossRef]

13. Bravi, L.; Santos, G.; Pagano, A.; Murmura, F. Environmental management system according to ISO $14001: 2015$ as a driver to sustainable development. Corp. Soc. Responsib. Environ. Manag. 2020, 27, 2599-2614. [CrossRef]

14. Lamm, E.; Tosti-Kharas, J.; Williams, E.G. Read this article, but don't print it: Organizational citizenship behavior toward the environment. Group Organ. Manag. 2013, 38, 163-197. [CrossRef]

15. Gurmani, J.K.; Khan, N.U.; Khalique, M.; Yasir, M.; Obaid, A.; Sabri, N.A.A. Do Environmental Transformational Leadership Predicts Organizational Citizenship Behavior towards Environment in Hospitality Industry: Using Structural Equation Modelling Approach. Sustainability 2021, 13, 5594. [CrossRef]

16. Khan, N.U.; Wu, W.; Saufi, R.B.A.; Sabri, N.A.A.; Shah, A.A. Antecedents of Sustainable Performance in Manufacturing Organizations: A Structural Equation Modeling Approach. Sustainability 2021, 13, 897. [CrossRef]

17. Terrier, L.; Kim, S.; Fernandez, S. Who are the good organizational citizens for the environment? An examination of the predictive validity of personality traits. J. Environ. Psychol. 2016, 48, 185-190. [CrossRef]

18. Lamm, E.; Tosti-Kharas, J.; King, C.E. Empowering employee sustainability: Perceived organizational support toward the environment. J. Bus. Ethics 2015, 128, 207-220. [CrossRef]

19. Paillé, P.; Mejía-Morelos, J.H.; Marché-Paillé, A.; Chen, C.C.; Chen, Y. Corporate greening, exchange process among co-workers, and ethics of care: An empirical study on the determinants of pro-environmental behaviors at coworkers-level. J. Bus. Ethics 2016, 136, 655-673. [CrossRef]

20. Liu, Z.; Mei, S.; Guo, Y. Green human resource management, green organization identity and organizational citizenship behavior for the environment: The moderating effect of environmental values. Chin. Manag. Stud. 2020, 15, 290-304. [CrossRef]

21. Ones, D.S.; Dilchert, S. Environmental sustainability at work: A call to action. Ind. Organ. Psychol. 2012, 5, 444-466. [CrossRef]

22. Neessen, P.C.; de Jong, J.P.; Caniëls, M.C.; Vos, B. Circular purchasing in Dutch and Belgian organizations: The role of intrapreneurship and organizational citizenship behavior towards the environment. J. Clean. Prod. 2021, 280, 124978. [CrossRef]

23. Alt, E.; Spitzeck, H. Improving environmental performance through unit-level organizational citizenship behaviors for the environment: A capability perspective. J. Environ. Manag. 2016, 182, 48-58. [CrossRef]

24. Rezapouraghdam, H.; Alipour, H.; Darvishmotevali, M. Employee workplace spirituality and pro-environmental behavior in the hotel industry. J. Sustain. Tour. 2018, 26, 740-758. [CrossRef]

25. Yuriev, A.; Boiral, O.; Guillaumie, L. Evaluating determinants of employees' pro-environmental behavioral intentions. Int. J. Manpow. 2020, 41, 1005-1019. [CrossRef]

26. Boiral, O.; Talbot, D.; Paillé, P. Leading by example: A model of organizational citizenship behavior for the environment. Bus. Strategy Environ. 2015, 24, 532-550. [CrossRef]

27. Khan, N.U.; Bhatti, M.N.; Obaid, A.; Sami, A.; Ullah, A. Do green human resource management practices contribute to sustainable performance in manufacturing industry? Int. J. Environ. Sustain. Dev. 2020, 19, 412-432. [CrossRef] 
28. Khan, N.U.; Saufi, R.B.A.; Obaid, A. Do Green HRM Practices Matter in Shaping Sustainable Performance Among ISO 14001Certified Malaysian Manufacturing Firms? A Mixed-Method Approach. In New Horizons in Management, Leadership and Sustainability; Springer: Heidelberg, Germany, 2021; pp. 219-236.

29. Ehnert, I.; Parsa, S.; Roper, I.; Wagner, M.; Muller-Camen, M. Reporting on sustainability and HRM: A comparative study of sustainability reporting practices by the world's largest companies. Int. J. Hum. Resour. Manag. 2016, 27, 88-108. [CrossRef]

30. Mazur, B. Sustainable human resource management. The attempt of holistic approach. Ekon. Zarz. 2015, 7, 7-12.

31. De Prins, P.; Van Beirendonck, L.; De Vos, A.; Segers, J. Sustainable HRM: Bridging theory and practice through the 'Respect Openness Continuity (ROC)'-model. Manag. Rev. 2014, 25, 263-284. [CrossRef]

32. Renwick, D.W.; Redman, T.; Maguire, S. Green human resource management: A review and research agenda. Int. J. Manag. Rev. 2013, 15, 1-14. [CrossRef]

33. Jackson, S.E.; Renwick, D.W.; Jabbour, C.J.; Muller-Camen, M. State-of-the-art and future directions for green human resource management: Introduction to the special issue. Ger. J. Hum. Resour. Manag. 2011, 25, 99-116. [CrossRef]

34. Jabbour, C.J.C.; de Sousa Jabbour, A.B.L.; Govindan, K.; Teixeira, A.A.; de Souza Freitas, W.R. Environmental management and operational performance in automotive companies in Brazil: The role of human resource management and lean manufacturing. J. Clean. Prod. 2013, 47, 129-140. [CrossRef]

35. Jackson, S.E.; Seo, J. The greening of strategic HRM scholarship. Organ. Manag. J. 2010, 7, 278-290. [CrossRef]

36. Stringer, L. The Green Workplace: Sustainable Strategies that Benefit Employees, the Environment, and the Bottom Line; St. Martin's Press: New York, NY, USA, 2010.

37. Garavan, T.N.; McGuire, D. Human resource development and society: Human resource development's role in embedding corporate social responsibility, sustainability, and ethics in organizations. Adv. Dev. Hum. Resour. 2010, 12, 487-507. [CrossRef]

38. Liebowitz, J. The role of HR in achieving a sustainability culture. J. Sustain. Dev. 2010, 3, 50. [CrossRef]

39. Delmas, M.A.; Pekovic, S. Environmental standards and labor productivity: Understanding the mechanisms that sustain sustainability. J. Organ. Behav. 2013, 34, 230-252. [CrossRef]

40. Govindarajulu, N.; Daily, B.F. Motivating employees for environmental improvement. Ind. Manag. Data Syst. 2004, 104, 364-372. [CrossRef]

41. Daily, B.F.; Bishop, J.W.; Steiner, R. The mediating role of EMS teamwork as it pertains to HR factors and perceived environmental performance. J. Appl. Bus. Res. 2011, 104, 64-372. [CrossRef]

42. Fernández, E.; Junquera, B.; Ordiz, M. Organizational culture and human resources in the environmental issue: A review of the literature. Int. J. Hum. Resour. Manag. 2003, 14, 634-656. [CrossRef]

43. Phillips, L. Go green to gain the edge over rivals. People Manag. 2007, 23, 1-9.

44. Jabbour, C.J.C.; Santos, F.C.A.; Nagano, M.S. Contributions of HRM throughout the stages of environmental management: Methodological triangulation applied to companies in Brazil. Int. J. Hum. Resour. Manag. 2010, 21, 1049-1089. [CrossRef]

45. Ji, L.; Huang, J.; Liu, Z.; Zhu, H.; Cai, Z. The effects of employee training on the relationship between environmental attitude and firms' performance in sustainable development. Int. J. Hum. Resour. Manag. 2012, 23, 2995-3008. [CrossRef]

46. Mandip, G. Green HRM: People management commitment to environmental sustainability. Res. J. Recent Sci. $2012,1,244-252$.

47. Wagner, M. 'Green'human resource benefits: Do they matter as determinants of environmental management system implementation? J. Bus. Ethics 2013, 114, 443-456. [CrossRef]

48. Renwick, D.; Redman, T.; Maguire, S. Green HRM: A review, process model, and research agenda. Univ. Sheff. Manag. Sch. Discuss. Pap. 2008, 2008, 1-46.

49. Paillé, P.; Chen, Y.; Boiral, O.; Jin, J. The impact of human resource management on environmental performance: An employeelevel study. J. Bus. Ethics 2014, 121, 451-466. [CrossRef]

50. Zibarras, L.D.; Coan, P. HRM practices used to promote pro-environmental behavior: A UK survey. Int. J. Hum. Resour. Manag. 2015, 26, 2121-2142. [CrossRef]

51. Ahmad, S. Green human resource management: Policies and practices. Cogent Bus. Manag. 2015, 2, 1030817. [CrossRef]

52. Jabbour, C.J.C.; de Sousa Jabbour, A.B.L. Green human resource management and green supply chain management: Linking two emerging agendas. J. Clean. Prod. 2016, 112, 1824-1833. [CrossRef]

53. Guerci, M.; Carollo, L. A paradox view on green human resource management: Insights from the Italian context. Int. J. Hum. Resour. Manag. 2016, 27, 212-238. [CrossRef]

54. Haddock-Millar, J.; Sanyal, C.; Müller-Camen, M. Green human resource management: A comparative qualitative case study of a United States multinational corporation. Int. J. Hum. Resour. Manag. 2016, 27, 192-211. [CrossRef]

55. O'Donohue, W.; Torugsa, N. The moderating effect of 'Green'HRM on the association between proactive environmental management and financial performance in small firms. Int. J. Hum. Resour. Manag. 2016, 27, 239-261. [CrossRef]

56. Gholami, H.; Rezaei, G.; Saman, M.Z.M.; Sharif, S.; Zakuan, N. State-of-the-art Green HRM System: Sustainability in the sports center in Malaysia using a multi-methods approach and opportunities for future research. J. Clean. Prod. 2016, 124, 142-163. [CrossRef]

57. Tang, G.; Chen, Y.; Jiang, Y.; Paillé, P.; Jia, J. Green human resource management practices: Scale development and validity. Asia Pac. J. Hum. Resour. 2017, 56, 31-55. [CrossRef]

58. Cheema, S.; Javed, F. The effects of corporate social responsibility toward green human resource management: The mediating role of sustainable environment. Cogent Bus. Manag. 2017, 4, 1310012. [CrossRef] 
59. Wehrmeyer, W. Human resources and environmental management. In Greening People; Routledge: London, UK, 2017.

60. Milliman, J.; Clair, J. Best environmental HRM practices in the US. In Greening People; Routledge: London, UK, 2017 ; pp. 49-73.

61. Zaid, A.A.; Jaaron, A.A.; Bon, A.T. The impact of green human resource management and green supply chain management practices on sustainable performance: An empirical study. J. Clean. Prod. 2018, 204, 965-979. [CrossRef]

62. Kim, Y.J.; Kim, W.G.; Choi, H.-M.; Phetvaroon, K. The effect of green human resource management on hotel employees eco-friendly behavior and environmental performance. Int. J. Hosp. Manag. 2019, 76, 83-93. [CrossRef]

63. Saeed, B.B.; Afsar, B.; Hafeez, S.; Khan, I.; Tahir, M.; Afridi, M.A. Promoting employee's proenvironmental behavior through green human resource management practices. Corp. Soc. Responsib. Environ. Manag. 2019, 26, 424-438. [CrossRef]

64. Pham, N.T.; Tučková, Z.; Jabbour, C.J.C. Greening the hospitality industry: How do green human resource management practices influence organizational citizenship behavior in hotels? A mixed-methods study. Tour. Manag. 2019, 72, 386-399. [CrossRef]

65. Mariappanadar, S. Sustainable Human Resource Management: Strategies, Practices and Challenges; Macmillan International Higher Education, Red Glob Press: London, UK, 2019.

66. Islam, M.A.; Hunt, A.; Jantan, A.H.; Hashim, H.; Chong, C.W. Exploring challenges and solutions in applying green human resource management practices for the sustainable workplace in the ready-made garment industry in Bangladesh. Bus. Strategy Dev. 2020, 3, 332-343. [CrossRef]

67. Hameed, Z.; Khan, I.U.; Islam, T.; Sheikh, Z.; Naeem, R.M. Do green HRM practices influence employees' environmental performance? Int. J. Manpow. 2020, 41, 1061-1079. [CrossRef]

68. Mousa, S.K.; Othman, M. The impact of green human resource management practices on sustainable performance in healthcare organisations: A conceptual framework. J. Clean. Prod. 2020, 243, 118595. [CrossRef]

69. Paillé, P.; Boiral, O.; Chen, Y. Linking environmental management practices and organizational citizenship behaviour for the environment: A social exchange perspective. Int. J. Hum. Resour. Manag. 2013, 24, 3552-3575. [CrossRef]

70. Lülfs, R.; Hahn, R. Corporate greening beyond formal programs, initiatives, and systems: A conceptual model for voluntary pro-environmental behavior of employees. Eur. Manag. Rev. 2013, 10, 83-98. [CrossRef]

71. Organ, D.W. Organizational Citizenship Behavior: The Good Soldier Syndrome; Lexington Books/DC Heath and Com, American Psychological Association: Washington, DC, USA, 1988.

72. Luu, T.T. CSR and organizational citizenship behavior for the environment in hotel industry. Int. J. Contemp. Hosp. Manag. 2017, 29, 2867-2900. [CrossRef]

73. Paillé, P.; Morelos, J.H.M.; Raineri, N.; Stinglhamber, F. The influence of the immediate manager on the avoidance of non-green behaviors in the workplace: A three-wave moderated-mediation model. J. Bus. Ethics 2019, 155, 723-740. [CrossRef]

74. Imperatives, S. Report of the World Commission on Environment and Development. In Our Common Future; Oxford University Press: Oxford, UK, 1987; Available online: https://www.are.admin.ch/are/en/home/media/publications/sustainabledevelopment/brundtland-report.html (accessed on 1 June 2021).

75. ISO 14001: Environmental Management Systems-Requirements with Guidance for Use; ISO: London, UK, 2015; Available online: https: / / www.iso.org/standard/60857.html (accessed on 1 June 2021).

76. Bansal, P.; Bogner, W.C. Deciding on ISO 14001: Economics, institutions, and context. Long Range Plan. 2002, 35, 269-290. [CrossRef]

77. Testa, F.; Rizzi, F.; Daddi, T.; Gusmerotti, N.M.; Frey, M.; Iraldo, F. EMAS and ISO 14001: The differences in effectively improving environmental performance. J. Clean. Prod. 2014, 68, 165-173. [CrossRef]

78. Delmas, M.A.; Montes-Sancho, M.J. An institutional perspective on the diffusion of international management system standards: The case of the environmental management standard ISO 14001. Bus. Ethics Q. 2011, 21, 103-132. [CrossRef]

79. Prajogo, D.; Tang, A.K.; Lai, K.-h. Do firms get what they want from ISO 14001 adoption?: An Australian perspective. J. Clean. Prod. 2012, 33, 117-126. [CrossRef]

80. Lai, K.-H.; Wong, C.W. Green logistics management and performance: Some empirical evidence from Chinese manufacturing exporters. Omega 2012, 40, 267-282. [CrossRef]

81. Prajogo, D.; KY Tang, A.; Lai, K.-H. The diffusion of environmental management system and its effect on environmental management practices. Int. J. Oper. Prod. Manag. 2014, 34, 565-585. [CrossRef]

82. Henriques, A.; Richardson, J. The Triple Bottom Line: Does It All Add Up; Routledge: London, UK, 2013.

83. Sridhar, K.; Jones, G. The three fundamental criticisms of the Triple Bottom Line approach: An empirical study to link sustainability reports in companies based in the Asia-Pacific region and TBL shortcomings. Asian J. Bus. Ethics 2013, 2, 91-111. [CrossRef]

84. Fauzi, H.; Svensson, G.; Rahman, A.A. "Triple bottom line" as "sustainable corporate performance": A proposition for the future. Sustainability 2010, 2, 1345-1360. [CrossRef]

85. Norman, W.; MacDonald, C. Getting to the bottom of "triple bottom line". Bus. Ethics Q. 2004, 14, 243-262. [CrossRef]

86. Yong, J.Y.; Yusliza, M.Y.; Ramayah, T.; Chiappetta Jabbour, C.J.; Sehnem, S.; Mani, V. Pathways towards sustainability in manufacturing organizations: Empirical evidence on the role of green human resource management. Bus. Strategy Environ. 2020, 29, 212-228. [CrossRef]

87. Bryman, A. Barriers to integrating quantitative and qualitative research. J. Mix. Methods Res. 2007, 1, 8-22. [CrossRef]

88. Creswell, J.W.; Creswell, J.D. Research Design: Qualitative, Quantitative, and Mixed Methods Approaches; Sage Publications: New York, NY, USA, 2017.

89. Mackenzie, N.; Knipe, S. Research dilemmas: Paradigms, methods and methodology. Issues Educ. Res. 2006, 16, $193-205$. 
90. Saunders, M.; Lewis, P.; Thornhill, A. Research Methods for Business Students (6. Utg.); Pearson: London, UK, 2012.

91. Eisenhardt, K.M. Building theories from case study research. Acad. Manag. Rev. 1989, 14, 532-550. [CrossRef]

92. Boselie, P.; Dietz, G.; Boon, C. Commonalities and contradictions in HRM and performance research. Hum. Resour. Manag. J. 2005, 15, 67-94. [CrossRef]

93. Guest, D.E. Human resource management and performance: Still searching for some answers. Hum. Resour. Manag. J. 2011, 21, 3-13. [CrossRef]

94. Teixeira, A.A.; Jabbour, C.J.C.; de Sousa Jabbour, A.B.L. Relationship between green management and environmental training in companies located in Brazil: A theoretical framework and case studies. Int. J. Prod. Econ. 2012, 140, 318-329. [CrossRef]

95. Zoogah, D.B. The dynamics of Green HRM behaviors: A cognitive social information processing approach. Ger. J. Hum. Resour. Manag. 2011, 25, 117-139. [CrossRef]

96. Jabbour, C.J.C. Environmental training in organisations: From a literature review to a framework for future research. Resour. Conserv. Recycl. 2013, 74, 144-155. [CrossRef]

97. Yusliza, M.-Y.; Othman, N.Z.; Jabbour, C.J.C. Deciphering the implementation of green human resource management in an emerging economy. J. Manag. Dev. 2017, 36, 1230-1246. [CrossRef]

98. Dubey, R.; Gunasekaran, A.; Papadopoulos, T.; Childe, S.J. Green supply chain management enablers: Mixed methods research. Sustain. Prod. Consum. 2015, 4, 72-88. [CrossRef]

99. Fayyazi, M.; Shahbazmoradi, S.; Afshar, Z.; Shahbazmoradi, M. Investigating the barriers of the green human resource management implementation in oil industry. Manag. Sci. Lett. 2015, 5, 101-108. [CrossRef]

100. FMM Directory of Malaysian Industries, 46th ed.; Federation of Malaysian Manufacturers: Kuala Lumpur, Malaysia, 2018; Available online: https: / / www.fmm.org.my/publications_list.aspx (accessed on 1 June 2021).

101. Castillo-Montoya, M. Preparing for Interview Research: The Interview Protocol Refinement Framework. Qual. Rep. 2016, 21, 811-831.

102. Maxwell, J.A. Qualitative Research Design; Sage Publications: Los Angeles, CA, USA, 2019.

103. Merriam, S.B.; Tisdell, E.J. Qualitative Research: A Guide to Design and Implementation; John Wiley \& Sons: New York, NY, USA, 2015.

104. Sekaran, U.; Bougie, R. Research Methods for Business: A Skill Building Approach; John Wiley \& Sons: New York, NY, USA, 2016.

105. Tashakkori, A.; Creswell, J.W. The New Era of Mixed Methods. J. Mix. Methods Res. 2007, 1, 3-7. [CrossRef]

106. Moser, A.; Korstjens, I. Series: Practical guidance to qualitative research. Part 3: Sampling, data collection and analysis. Eur. J. Gen. Pract. 2018, 24, 9-18. [CrossRef]

107. Green, J.; Thorogood, N. Qualitative Methods for Health Research; Sage publications: New York, NY, USA, 2018.

108. Miles, M.B.; Huberman, A.M. Qualitative Data Analysis: An Expanded Sourcebook; Sage Publications: New York, NY, USA, 1994.

109. Attride-Stirling, J. Thematic networks: An analytic tool for qualitative research. Qual. Res. 2001, 1, 385-405. [CrossRef]

110. Bernard, H.R.; Wutich, A.; Ryan, G.W. Analyzing Qualitative Data: Systematic Approaches; Sage Publications: New York, NY, USA, 2016.

111. Braun, V.; Clarke, V. Using thematic analysis in psychology. In Qualitative Research in Psychology; McGraw-Hill Education: New York, NY, USA, 2013.

112. Edhlund, B.; McDougall, A. NVivo for Mac Essentials; Lulu. com: Morrisville, CA, USA, 2016.

113. Woods, M.; Paulus, T.; Atkins, D.P.; Macklin, R. Advancing qualitative research using qualitative data analysis software (QDAS)? Reviewing potential versus practice in published studies using ATLAS. ti and NVivo, 1994-2013. Soc. Sci. Comput. Rev. 2016, 34, 597-617. [CrossRef]

114. Ivankova, N.V. Implementing quality criteria in designing and conducting a sequential QUAN $\rightarrow$ QUAL mixed methods study of student engagement with learning applied research methods online. J. Mix. Methods Res. 2014, 8, 25-51. [CrossRef]

115. Klemeš, J.J.; Varbanov, P.S.; Huisingh, D. Recent cleaner production advances in process monitoring and optimisation. J. Clean. Prod. 2012, 34, 1-8. [CrossRef]

116. Khan Noor, U. Green Human Resource Management Practices among ISO14001-certified Malaysian Manufacturing Firms. In Green Behavior and Corporate Social Responsibility in Asia; Saufi Roselina, A., Farzana, Q., Jihad, M., Eds.; Emerald Publishing Limited: Bentley, UK, 2019; pp. 73-79.

117. Krut, R.; Gleckman, H. ISO 14001: A Missed Opportunity for Sustainable Global Industrial Development; Routledge: London, UK, 2013.

118. Department of Statistics Malaysia. Available online: https:/ / www.statistics.gov.my/ (accessed on 25 August 2020). 